\title{
Nanoparticles mediated cadmium toxicity amelioration in plants
}

\author{
Sharmily Chakraborty ${ }^{1}$, Suparna $\mathrm{Pal}^{1^{*}}$ \& Subhabrata Paul ${ }^{2}$ \\ ${ }^{1}$ Department of Botany, Lady Brabourne College, P-1/2 Suhrawardy Avenue, Kolkata 700 017, India \\ ${ }^{2}$ School of Biotechnology, Presidency University, New Town, Kolkata 700 156, India \\ *Email: suparnap486@gmail.com
}

\section{ARTICLE HISTORY}

Received: 08 May 2021

Accepted: 19 July 2021

Available online: 26 August 2021

KEYWORDS

Cadmium

Hyperaccumulator

Antioxidants

Nanomaterial

Silicon dioxide

Nano zero valent iron

Nanofertilizer

\begin{abstract}
Application of nanoparticles to address various environmental issues; especially heavy metal contaminated soil restoration is of global interest. Indiscriminate usage of phosphate fertilizer and other anthropogenic activities contribute to $\mathrm{Cd}$ contamination of soil, resulting in degradation of soil quality and low crop yield. By the virtue of unique physiochemical characteristics, nanoparticles (NPs) are effective enough for heavy metal stress mitigation. This review has focused on $\mathrm{Cd}$ uptake, accumulation and toxicity in plants followed by the successful application of different metallic and non metallic NPs for soil Cd decontamination. Positive impact of NPs as plant growth elicitor under Cd stress has been explored here. Various ways of NP application (soil, foliar, hydroponics), uptake, mode of action and effective treatment concentration have been highlighted. We have collected handful information regarding the use of NPs as nanofertilizer and nanopesticides. The negative effects of NPs have not been considered here. More in depth study to be conducted for better illumination on plant NPs interaction, mobilization mechanism and biological activities. Though this review summarizes few facts among various aspect of NP but can be counted as a supportive documentation for the better use of NPs in environmental protection in future.
\end{abstract}

\section{Introduction}

Rapid industrialization, indiscriminate usage of agrochemicals and fertilizers, excessive mining has led to heavy metal (HM) soil contamination a global burning issue. HM pollution of soil is one of the critical issues hampering crop yield and limiting food security. Being non biodegradable; bioaccumulation of heavy metal (loid)s in soil imparts severe ecological risk to the biome. Cadmium (67th element in order of abundance) is one of the most toxic heavy metals that get deposited in soils through natural or anthropological means like mining, smelting, battery manufacturing etc (1). By the virtue of better water solubility and mobility cadmium (Cd) is easily taken up by plants via ascent of sap in roots followed by transportation to shoot through membrane embedded metal ATPase (2). It can cause potential damage to living organisms, even at very low concentrations, thus considered as the fourth most toxic element in (3) the environment. $\mathrm{Cd}$ is ranked third globally, following mercury and lead in the list of most hazardous contaminants by the US Environmental Protection Agency (EPA). Biologically non essential Cd is quite efficient to replace important mineral calcium owes to its similar chemical structure and behaviour
(4) resulting easy passage in plant and animal tissues through the food chain.

Continuous persistence of $\mathrm{Cd}$ in soil not only interferes in plant physiology but also alters soil properties such as $\mathrm{pH}$, organic matter affecting important minerals (Fe, P, Ca, Mn) uptake by plants (5). The main visible signs of Cd toxicity are chlorosis, leaf rolling, compromised growth and ultimate necrosis in plants under higher concentration (6). Beside occupational exposure, other route of $\mathrm{Cd}$ poisoning in human is the ingestion of $\mathrm{Cd}$ contaminated foods (cereals, leafy vegetables) which contain more $\mathrm{Cd}$ in comparison to animal products (meat, egg, milk) (7). Mainly the accumulation of $\mathrm{Cd}$ in staple food rice and its transfer to the successive trophic levels has become a major environmental concern (8). Kidney and livers are the two most affected organs account for the maximum $\mathrm{Cd}$ accumulation in the human body (7). The presence of $\mathrm{Cd}$ poses serious threat to humans like anaemia, cardiac failure, kidney malfunction and osteoporosis (9). The 'Itai-Itai' disease in humans was caused due to consumption of Cd-polluted rice (10). According to WHO the allowable limits of $\mathrm{Cd}$ concentration in soil is $0.2 \mathrm{mg} / \mathrm{kg}$ (11). Many attempts have been adopted to address the issue of $\mathrm{Cd}$ decontamination of soil that

(c) Chakraborty et al. (2021). This is an open-access article distributed under the terms of the Creative Commons Attribution License, which permits unrestricted use, distribution and reproduction in any medium, provided the original author and source are credited (https://creativecommons.org/licenses/by/4.0/). 
includes chemical clean up, phytoremediation and recently nanotechnology also.

Nanotechnology is a rapidly emerging field of research, which involves the study and development of nanoparticles (NPs) and has gained a huge momentum in remediation of metal contaminated soil and water and environmental protection. According to ASTM standards, Nanomaterials (NMs) is a natural or engineered material, with a dimension of 1-100 nm (12). The small size and a high surface-tovolume ratio of NMs offer better adsorption capacity. Nano-materials like nZVI, carbon nanotubes, nanosilica, graphene or hybrid metal-non-metal nanoparticles are extensively utilized for soil decontamination. The unique physical properties of NPs (small size, porosity, high surface-area and better absorption) provide additional advantages as compared to the traditional methods, as efficient materials for environmental remediation. Due to minimum toxic effect, iron oxide NPs are of maximum use (13). Various studies have proven the effectiveness of NPs in immobilization of heavy metal (loid)s, thereby decreasing their bioavailability. Several reports indicated the positive impact of NPs on plant seed germination, photosynthesis, antioxidative defense, growth, and crop quality (14, 15). Selenium and silicon NPs mitigates $\mathrm{Cd}$ and $\mathrm{Pb}$ toxicity in rice via foliar spray (16). Foliar application of $\mathrm{TiO}_{2}$ NPs had better response than soil treatment for $\mathrm{Cd}$ toxicity alleviation in maize. Successful use of NPs as nanofertilizers $(17,18)$ and nanopesticides (19), have been globally accepted but the potential ecological hazards can't be ruled out (20). This review is a comprehensive summary of many recent studies, with keen focus on the application of various NPs and their effectiveness in the mitigation of $\mathrm{Cd}$ toxicity in plants. But the phytotoxicity of NPs has not been considered here in details.

\section{Cadmium contamination in environment}

Soil and groundwater contamination due to leaching effect of Cd has enough global reports (21). Devoid of any microbial and biochemical degradation, persistence of soil $\mathrm{Cd}$ is a continuous threat to the biota. Non-essential heavy metal Cadmium (Cd), is mostly released into the environment through metal industries, mining, smelting and other anthropogenic activities like application of fertilizers, sewage sludge, in various industrial usage such as metal plating and as neutron absorbent in nuclear reactors (22). Having detectable percentage of $\mathrm{Cd}$ impurity phosphate fertilizer (4) is a potential Cd donor to soil. Not only MSW but also electrical stress tolerant Cd-Ni batteries are distinct contributors to soil Cd (23). The air-borne source of $\mathrm{Cd}$ is burning of fossil fuels and emission through iron and steel factories. Certain plants like rice, potato, tobacco and other leafy vegetables can uptake $\mathrm{Cd}$ more avidly as compared to other heavy metals like lead and mercury (24). Safe limit of Cd as suggested by World Health Organization (WHO) is

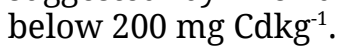

\section{Plant response to bio-available Cadmium}

Cd toxicity has a comprehensive negative interference with all the metabolic pathways including water relations, photosynthetic rate, respiration, transpiration, stomatal conductance (25, 26). Response of plants to elevated soil $\mathrm{Cd}$ concentration is cultivar specific as bioaccumulation capacity is genotype dependent (27). Cd mobility is a multivariant component that depends on various physicochemical properties of soil, but most important is the soil $\mathrm{pH}$ which is indirectly proportional to Cd bioavailability (28). Root exudates always decrease $\mathrm{Cd}$ accessibility to plants facilitating other micronutrients uptake (28). Cd is absorbed by roots either as inorganic complexes $\left(\mathrm{Cd}^{2+} \mathrm{SO}_{4}, \mathrm{CdCl}_{2}\right)$, or as organic forms (phytometallophore) (4). Presence of other cations in soil antagonizes $\mathrm{Cd}$ availability as they vigorously compete for the binding site of plants roots (28). Cadmium being a non-essential heavy metal, its presence exerts serious adverse effects in plants (Fig. 1). Acute damage of root and shoot morphology in various crops such as rice and wheat $(2,16,29)$ is a well known fact. The stunted growth of Cd treated plants is directly related to reduced nutrient, water availability and enzymatic degradation of respiration, photosynthesis, nitrogen

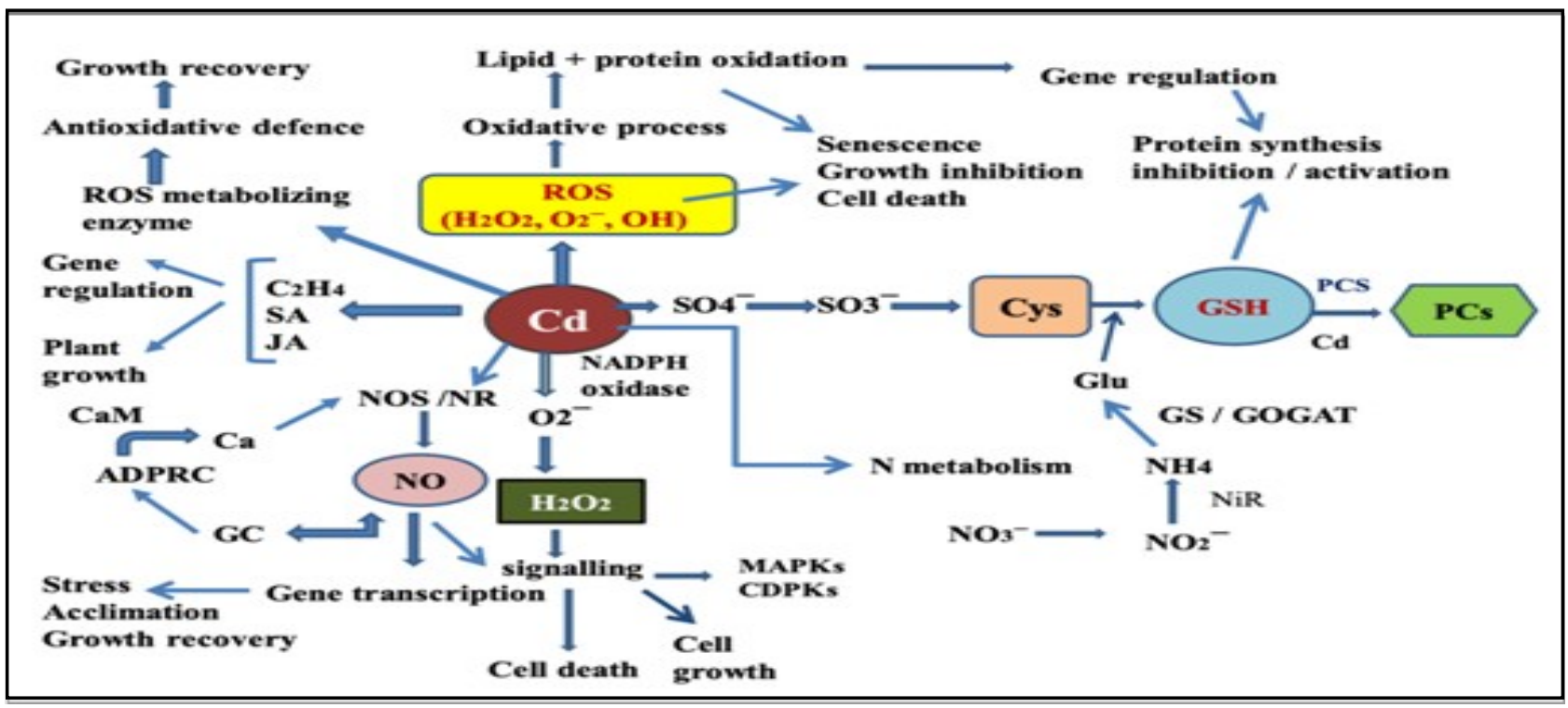

Fig. 1. Cd induced reactive oxygen species generation and oxidative stress in plants. 
fixation (30). Inhibition of seed germination is the prime symptoms of soil $\mathrm{Cd}$ exposure which is attributed to the decline in water absorption followed by cessation of starch mobilization into embryo (31). Due to compromise in a amylase activity, a significant decline in starch release has been reported earlier in $\mathrm{Cd}$ treated barley seed (32). Growth reduction of $\mathrm{Cd}$ stressed rice due to root shoot translocation and grain accumulation (33) is a proven fact and directly related to low yield of other crop (wheat) plants (34). Plants grown on Cdcontaminated soil suffer from nutrient deficiency as Cd interferes with mineral uptake (35) among which Fe deficiency is most prominent. Significant decrease in N, Ca, Mg and P uptake in alfalfa (36) and Atriplex halimus (37) has been recorded earlier. Being non essential element $\mathrm{Cd}$ specific transporter is unavailable in plants, so $\mathrm{Cd}$ is taken up via iron transporter which is evident by the elevated expression of divalent cation transporter IRT1 (Iron regulated transporter) in Cd stressed Solanum torvum (38). Oxidative stress due to heavy metal contamination is mainly ROS dependent. Reactive oxygen species (superoxide radical, hydroxyl radical, hydrogen peroxide) are traditional byproducts of metabolic pathways where they behave as signaling molecules (39) but overproduction of ROS under metal stress is detrimental for plants. Though $\mathrm{Cd}$ doesn't participate in Fenton reaction but $\mathrm{Cd}$ is the infamous causal agent of ROS accumulation mainly by disrupting electron transport chain in PSII followed by redox imbalance (40). These oxygen species directly attack on membrane lipids and proteins by amino acid modifications and degradation of peptide chains. ROS affect membrane integrity which is evident from malondialdehyde (MDA) production due to lipid peroxidation in rice (41) and many other plants. Excessive levels of $\mathrm{Cd}$ (100 mg Cd/kg of soil) induces chlorosis and root necrosis in rice followed by acute oxidative stress due to ROS generation (42) leading to significant decrease in root-shoot length (41). Cd contamination in soil indirectly imparts osmotic stress in plants by declining leaf water content and altering stomatal conductance (3). This was evident by the linear increase of proline accumulation with gradual rise in $\mathrm{Cd}$ contamination in rice $(41,43)$, sassafras seedling (44) and various other plants. Early reports supported the fact that elevation of proline accumulation has a positive impact in the maintenance of redox balance and cellular homeostasis when electron transport is hindered during adverse condition of Cd toxicity (45). Photosynthesis is extremely susceptible to $\mathrm{Cd}$ contamination. Decline in chlorophyll and carotenoid contents was due to the damage of the photosynthetic apparatus (PSI and PSII) and replacement of $\mathrm{Mg}^{2+}$ ions by $\mathrm{Ca}^{2+}$ ions from oxygen-evolving complex under $\mathrm{Cd}$ stress (46). In addition with light reaction, $\mathrm{CO}_{2}$ fixation is also hampered due to soil Cd exposure mainly by minimization of RuBPCase activity. Irreversible dissociation of RuBPCase subunits under $\mathrm{Cd}$ stress resulted complete cessation of this enzyme activity (47). Along with photosynthesis, Cd invades nitrogen metabolism in plants. Nitrate reductase and glutamine synthetase are the main target point for $\mathrm{Cd}$ induced nitrogen assimilation minimization in Silene cucubalus L. reducing root to shot transportation of nitrate (48). Due to size resemblance with $\mathrm{Ca}^{2+}$, cadmium interferes in $\mathrm{Ca}^{2+}$ mediated processes. According to the previous study $\mathrm{Cd}$ induced depolarization of root epidermal cell membrane declined $\mathrm{Ca}^{2+}$ uptake resulting growth impairment in $\mathrm{Cd}$ treated rice (49). In contrast, increase in cytosolic $\mathrm{Ca}^{2+}$ was recorded from $\mathrm{Cd}$ stressed yeast cell due to influx of $\mathrm{Ca}^{2+}$, followed by the upregulation of downstream genes involved in heavy metal transport (50). Cd strongly affects the pollens by reducing the germination rate of pollens and negatively affecting the pollen tube growth. It was observed under invitro studies, that $\mathrm{Cd}$ causes morphological abnormalities like swelling at the tips of pollen tubes (51). Genotoxic effect of $\mathrm{Cd}$ has been established in many plants in previous studies where $\mathrm{Cd}$ dependent ROS production is very often followed by DNA damage and mutagenesis leading to genomic instability via induction of single and double strand nicks and DNA-protein cross links (39).

\section{Cadmium tolerance in plants}

Plants handle Cd toxicity either by avoidance or by tolerance. Avoidance deals with the minimization of $\mathrm{Cd}$ uptake while tolerance (34) includes $\mathrm{Cd}$ accumulation followed by sequestration with different chelating molecules (peptides, proteins). Versatile strategies employed by plants to cope up with soil $\mathrm{Cd}$ load are; lowering the bioavailability of HM in the soil (52), down-regulating the HM transporter genes (53) and elevating the production of enzymatic and non-enzymatic antioxidant molecules (54). The first line of defense is scavenging of $\mathrm{Cd}$ in root vacuole by low molecular weight organic acids, polysaccharides and non-protein thiol (NPT, phytochelatin) compounds $(55,56)$ preventing its translocation to shoots (3). Sharp rise in the synthesis of $\mathrm{Cd}$ chelator low molecular weight peptide Phytochelatin (PC) is well documented in Cd stressed Eichhornia crassipes (55), Oryza sativa (57) and Arabidopsis (58) by upregulating phytochelatin synthase 1 gene. PC is well equipped to scavenge $\mathrm{Cd}$ for its detoxification. Plants enhance their tolerance capacity by increasing the production of stress signalling compounds (salicylic acid, jasmonic acid, nitric oxide and brassinosteroids) that are involved in the upregulation of various detoxification pathways during Cd toxicity (59). Plants have evolved various antioxidative enzymes such as catalase (CAT), peroxidase (POD), superoxide dismutase (SOD), glutathione reductase (GR) for direct detoxification of ROS. Studies have revealed that under moderate $\mathrm{Cd}$ toxicity rice plant stimulated their anti oxidative system (SOD, CAT) $(41,43)$, osmoregulation, ion homeostasis as well as increased the production of various signalling molecules (54). Studies revealed various genes involved in Cd tolerance in rice such as the Low Cadmium (LCD) gene responsible for $\mathrm{Cd}$ accumulation without hampering growth parameters (60). In Arabidopsis, cadmium stress-responsive gene AtFC1 was transcriptionally activated to elevate $\mathrm{Cd}$ tolerance by upregulating non protein thiol compound (glutathione and phytochelatins) production, that confers increase in root length, biomass, chlorophyll content with simultaneous decrease in free radicals (61). Subcellular 
compartmentalization and sequestration are mostly practiced in hyperaccumulators without acute visible symptoms of Cd toxicity (62). Positive effect of plant growth regulator (salicylic acid, gibberellin) in $\mathrm{Cd}$ remediation by reducing ROS generation and upregulating different antioxidative enzymes like SOD, CAT (63) and heat shock (stress) protein (64) production is a well established proven fact.

\section{Cd uptake and transport in plants}

Cadmium mainly exists in the soil in the form of divalent cation $\mathrm{Cd}^{2+}$. The bioavailability of $\mathrm{Cd}$ depends on the physicochemical characters of the soil, such as redox potential, soil $\mathrm{pH}$, organic matter and presence of other trace elements (65). The entry path of $\mathrm{Cd}^{2+}$ into the root is as follows (Fig. 2).

1. At the plasma membrane of root cells dissociation of $\mathrm{H}_{2} \mathrm{CO}_{3}$ into $\mathrm{H}^{+}$and $\mathrm{HCO}^{3-}$ followed by the exchange of $\mathrm{H}+$ with $\mathrm{Cd}^{2+}$ and its absorption (38).

2. $\mathrm{Cd}^{2+}$ enters through ion channels for other minerals $\mathrm{Fe}^{2+}, \mathrm{Zn}^{2+}$ and $\mathrm{Ca}^{2+}$ where it combines with transporter proteins and subsequently taken up by root epidermis via symplast pathway.

3. Mugineic acids, a siderophore secreted by plant (Poaceae) roots forms $\mathrm{Cd}^{2+}$ metal ligand complexes under Fe deficiency that facilitates $\mathrm{Cd}^{2+}$ uptake in root epidermis via YellowStripe 1- Like (YSL) proteins $(66,67)$.

\section{Genes involved in Cd uptake}

The process of $\mathrm{Cd}$ uptake and localization in plants has gathered the attention of scientists worldwide.
The recent technologies that are being utilized to detect $\mathrm{Cd}$ localization in plants are- ultramicroscopy, radioautography and energy dispersive X-ray microanalysis (EMAX). Several genes, responsible for encoding heavy metal transporters, have been identified in plants. A diverse range of proteins responsible for $\mathrm{Cd}$ uptake have been reported such as NRAMP family, P-type ATPase, ABC transporter, ZIP family and LCT transporter. Rice genome expresses several HMA genes, among which, OsHMA2 is of immense importance for $\mathrm{Cd}$ uptake. The physiological concentration of heavy metals in plant cell is mainly regulated by the optimum activity of metal transporters embedded in plasma membrane and tonoplast. Details of different genes involved in Cd import into the plants have been listed in Table 1. A diagrammatic representation of various $\mathrm{Cd}$ transporter proteins responsible for $\mathrm{Cd}$ sequestration is given in Fig. 3.

\section{Types of nanoparticles}

In modern era, application of nanomaterials is of paramount interest for addressing the problem of rapid increase of $\mathrm{Cd}$ contamination in agricultural lands. Nanomaterials have distinctive physicochemical characteristics that offer multifunctional use in plant science, not only to enhance crop productivity but also to ameliorate heavy metal toxicity. Depending on sizes, nanomaterial may be of different typesnanoparticles, nanosheets, nanowires, nanoflowers, nanotubes and nanorods (100). Recently, NPs mediated plant interactions, regarding metal uptake, mobilization and accumulation are of great interest and a few successfully engineered NPs have been

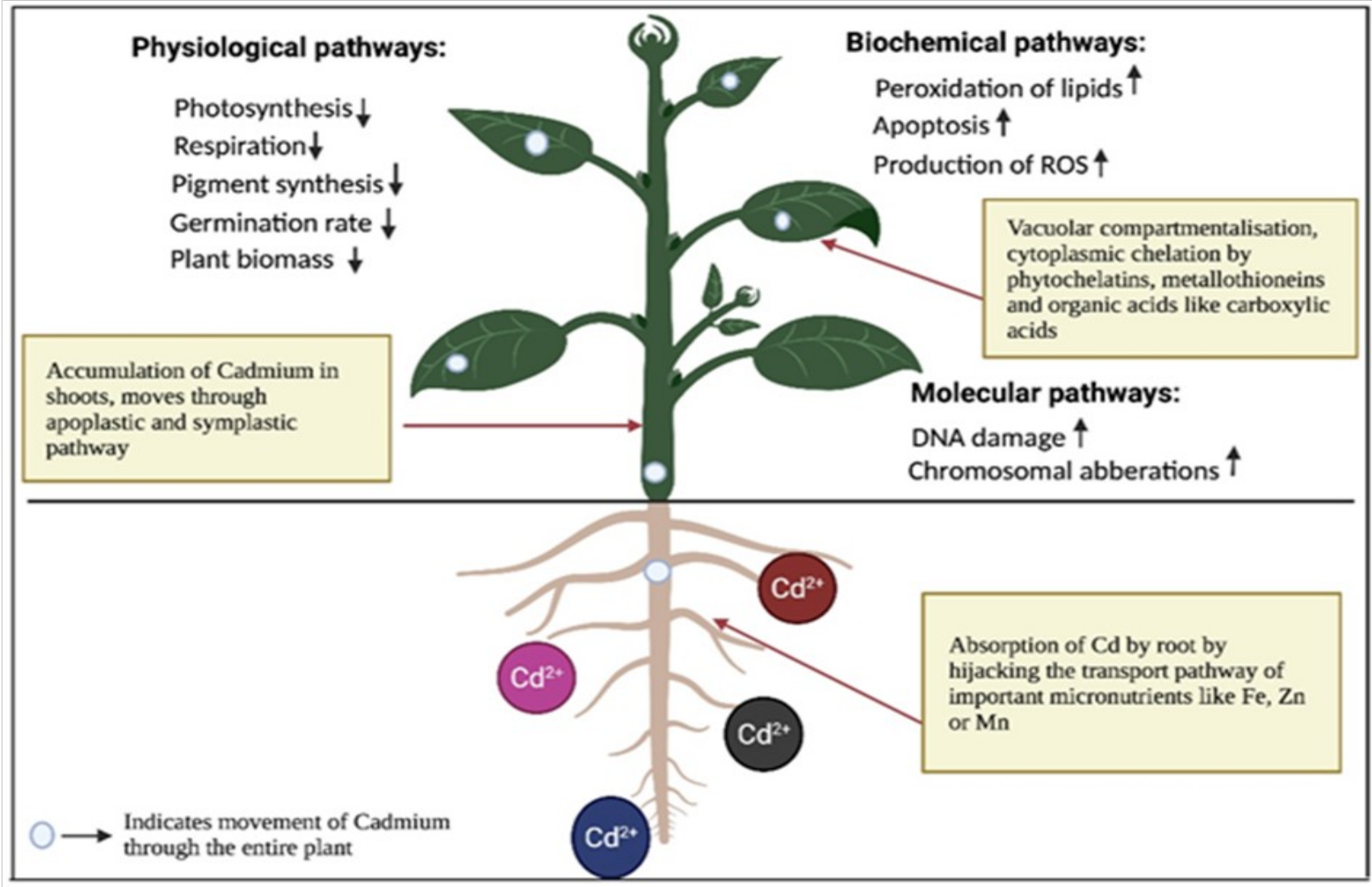

Fig. 2. Uptake and interference of Cd with different metabolic pathways in plants, downward and upward arrows indicate detrimental effects of Cd. 
Table 1. Genes involved in cadmium uptake in plants

\begin{tabular}{|c|c|c|c|c|c|c|}
\hline Function & Name & Annotation & $\begin{array}{l}\text { Organ of } \\
\text { expression }\end{array}$ & Plant species & $\begin{array}{l}\text { Co-transported } \\
\text { ions }\end{array}$ & References \\
\hline \multirow{6}{*}{$\begin{array}{l}\text { 1) Process of uptake } \\
\text { into cell }\end{array}$} & $\begin{array}{l}\text { IRT1 and } \\
\text { IRT12 }\end{array}$ & ZIP Family & Roots & $\begin{array}{l}\text { Oryza sativa, } \\
\text { Hordenum vulgare } \\
\text { Arabidopsis } \\
\text { thaliana, }\end{array}$ & 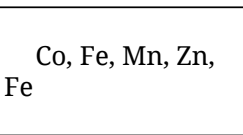 & $68,69,70$ \\
\hline & ZNT1 & ZIP Family & Roots, shoots & $\begin{array}{l}\text { Triticum aestivum, } \\
\text { Noccaea } \\
\text { caerulescens }\end{array}$ & $\mathrm{Zn}$ & 71,72 \\
\hline & LCT1 & $\begin{array}{l}\text { Low-affinity cation } \\
\text { transporters }\end{array}$ & Roots & Triticum aestivum & $\mathrm{Ca}, \mathrm{K}$ & 71 \\
\hline & $\overline{A N N 4}$ & Annexin & Roots & Oryza sativa & $\mathrm{Ca}$ & 73 \\
\hline & $\begin{array}{l}\text { NRAMP1, } \\
\text { NRAMP5 and } \\
\text { NRAMP6 }\end{array}$ & $\begin{array}{l}\text { Natural resistance- } \\
\text { associated } \\
\text { macrophage protein }\end{array}$ & Roots & $\begin{array}{l}\text { Triticum aestivum, } \\
\text { Zea mays, Oryza } \\
\text { sativa, Arabidopsis } \\
\text { thaliana }\end{array}$ & $\mathrm{Fe}, \mathrm{Mn}, \mathrm{Co}$ & $\begin{array}{l}\text { 71, 74,75, 76, } \\
\text { 77, }\end{array}$ \\
\hline & $\begin{array}{l}\text { YSL2 } 2 \text { and } \\
\text { YSL3 }\end{array}$ & $\begin{array}{l}\text { Yellow-Stripe Like } \\
\text { transporter }\end{array}$ & $\begin{array}{l}\text { Vascular bundles } \\
\text { and epidermal } \\
\text { cells of the roots }\end{array}$ & $\begin{array}{l}\text { Solanum nigrum, } \\
\text { Oryza sativa }\end{array}$ & $\mathrm{Fe}(\mathrm{II}), \mathrm{Cu}, \mathrm{Zn}, \mathrm{Ni}$ & 78,79 \\
\hline \multirow{2}{*}{$\begin{array}{l}\text { 2) Efflux out of the } \\
\text { cell }\end{array}$} & MTP9 & $\begin{array}{l}\text { Cation-diffusion } \\
\text { facilitator (CDF) }\end{array}$ & Root epidermis & Cucumis sativus & Mn & 80 \\
\hline & PDR8 & ATP-Binding Casette & $\begin{array}{l}\text { Roots(Hair and } \\
\text { epidermis), shoot }\end{array}$ & Arabidopsis thaliana & $\mathrm{Pb}$ & 81 \\
\hline \multirow{3}{*}{ 3) Chelation } & $M T L$ & MT-like protein & Roots & $\begin{array}{l}\text { Sedum } \\
\text { plumbizincicola }\end{array}$ & & 82 \\
\hline & $C D T 1$ & Cys-rich peptide & $\begin{array}{l}\text { Roots, shoots (cell } \\
\text { surface, cell-wall) }\end{array}$ & $\begin{array}{l}\text { Digitaria ciliaris, } O \text {. } \\
\text { sativa }\end{array}$ & & 83 \\
\hline & $\overline{C A L 1}$ & Defensin-like protein & Roots & Oryza sativa & & 84 \\
\hline \multirow{4}{*}{$\begin{array}{l}\text { 4) Uptake into } \\
\text { vacuole } \\
\text { sequestration }\end{array}$} & HMA3 & $\begin{array}{l}\text { P type ATPase family, } \\
\text { subfamily HMA(for } \\
\text { Heavy Metal } \\
\text { Associated) }\end{array}$ & $\begin{array}{l}\text { Vacuoles of roots } \\
\text { and shoots }\end{array}$ & $\begin{array}{l}\text { Sedum } \\
\text { plumbizincicola } \\
\text { Oryza sativa, } \\
\text { Brassica rapa }\end{array}$ & $\mathrm{Zn}, \mathrm{Co}, \mathrm{Pb}$ & $85,86,87$ \\
\hline & MRP3 & ATP-Binding Cassettes & Roots, shoots & Hordeum vulgare & & 88 \\
\hline & $\begin{array}{l}C A X 2 \text { and } \\
C A X 4 \\
\end{array}$ & Cation exchanger & $\begin{array}{l}\text { Tonoplast- } \\
\text { localized }\end{array}$ & $\begin{array}{l}\text { Arabidopsis } \\
\text { thaliana }\end{array}$ & $\mathrm{Ca}, \mathrm{Zn}, \mathrm{Mn}$ & 89,90 \\
\hline & $B C C 3$ & ATP-Binding Cassettes & $\begin{array}{l}\text { Roots and shoots } \\
\text { tonoplasts }\end{array}$ & Arabidopsis thaliana & Phytochelatin & 91 \\
\hline $\begin{array}{l}\text { 5) Efflux out of the } \\
\text { cell }\end{array}$ & $\begin{array}{l}\text { NRAMP3 and } \\
\text { NRAMP4 }\end{array}$ & $\begin{array}{l}\text { Natural resistance- } \\
\text { associated } \\
\text { macrophage protein }\end{array}$ & Roots, shoots & Thlaspi caerulescens & $\mathrm{Fe}, \mathrm{Mn}$ & 92 \\
\hline \multirow{3}{*}{ 6)Xylem loading } & $\begin{array}{l}\text { HMA2 and } \\
\text { HMA4 }\end{array}$ & $\begin{array}{l}\text { P-type ATPase family, } \\
\text { subfamily HMA(for } \\
\text { Heavy Metal } \\
\text { Associated) }\end{array}$ & Roots, shoots & $\begin{array}{l}\text { Arabidopsis } \\
\text { thaliana, Noccaea } \\
\text { caerulescen, Oryza } \\
\text { sativa }\end{array}$ & $\mathrm{Zn}, \mathrm{Pb}, \mathrm{Cu}$ & 93,94, 95 \\
\hline & MTP1 & $\begin{array}{l}\text { Cation-diffusion } \\
\text { facilitator (CDF) }\end{array}$ & Roots, Leaves & Oryza sativa & $\mathrm{Zn}$ & 96 \\
\hline & CCX2 & $\begin{array}{l}\text { Cation/Calcium }(\mathrm{Ca}) \\
\text { exchanger }\end{array}$ & Roots, shoots & Oryza sativa & $\mathrm{Ca}$ & 97 \\
\hline \multirow[b]{2}{*}{ 7)Phloem loading } & $L C T 1$ & $\begin{array}{l}\text { Low affinity cation } \\
\text { transporter }\end{array}$ & Shoot & Oryza sativa & $\mathrm{K}, \mathrm{Mg}, \mathrm{Ca}, \mathrm{Mn}$ & 98 \\
\hline & $H M A 2$ & $\begin{array}{l}\text { P-type ATPase family, } \\
\text { subfamily HMA(for } \\
\text { Heavy Metal } \\
\text { Associated) }\end{array}$ & Shoot (node) & Oryza sativa & $\mathrm{Zn}$ & 99 \\
\hline
\end{tabular}

tested positive in this field with the final goal of plant defense elicitation. Polymeric NP is gaining more attention now a days for being biocompatible, cheaper and being responsive to environmental stimuli (101). Commercially available Core NPs are prepared with different combination of organic and inorganic materials. The preference of NPs entirely depends on the ultimate targets and use.

Metallic nanoparticles- These are nano sized particles of dimensions within $100 \mathrm{~nm}$. These are the pure metallic state or oxides of gold, titanium, iron, gold, manganese, copper and many others. Metal oxides are more preferable due to better stability than pure metallic forms. Greater surface area makes them better absorber of small molecules (102).
Non-metallic nanoparticles- Major non-metallic carbon-based nanoparticles are fullerene and carbon nanotubes. Fullerenes are of great commercial value due to their electrical conductivity, high strength and versatility (103). Carbon-nanotubes are slender, elongated tubes of 1-2 $\mathrm{nm}$ diameter. They may be single-walled, double-walled or multi-walled carbon nanotubes that act as efficient adsorbents in environmental remediation.

Hybrid nanoparticles- These are formed by a mixture between metallic and non-metallic nanoparticles and by the virtue of improved properties these are preferred more as compared to the singular metallic or non-metallic nanoparticles. A metallic hybrid consisting of $\mathrm{ZnO}$ and $\mathrm{TiO}_{2}$ hybrid was 


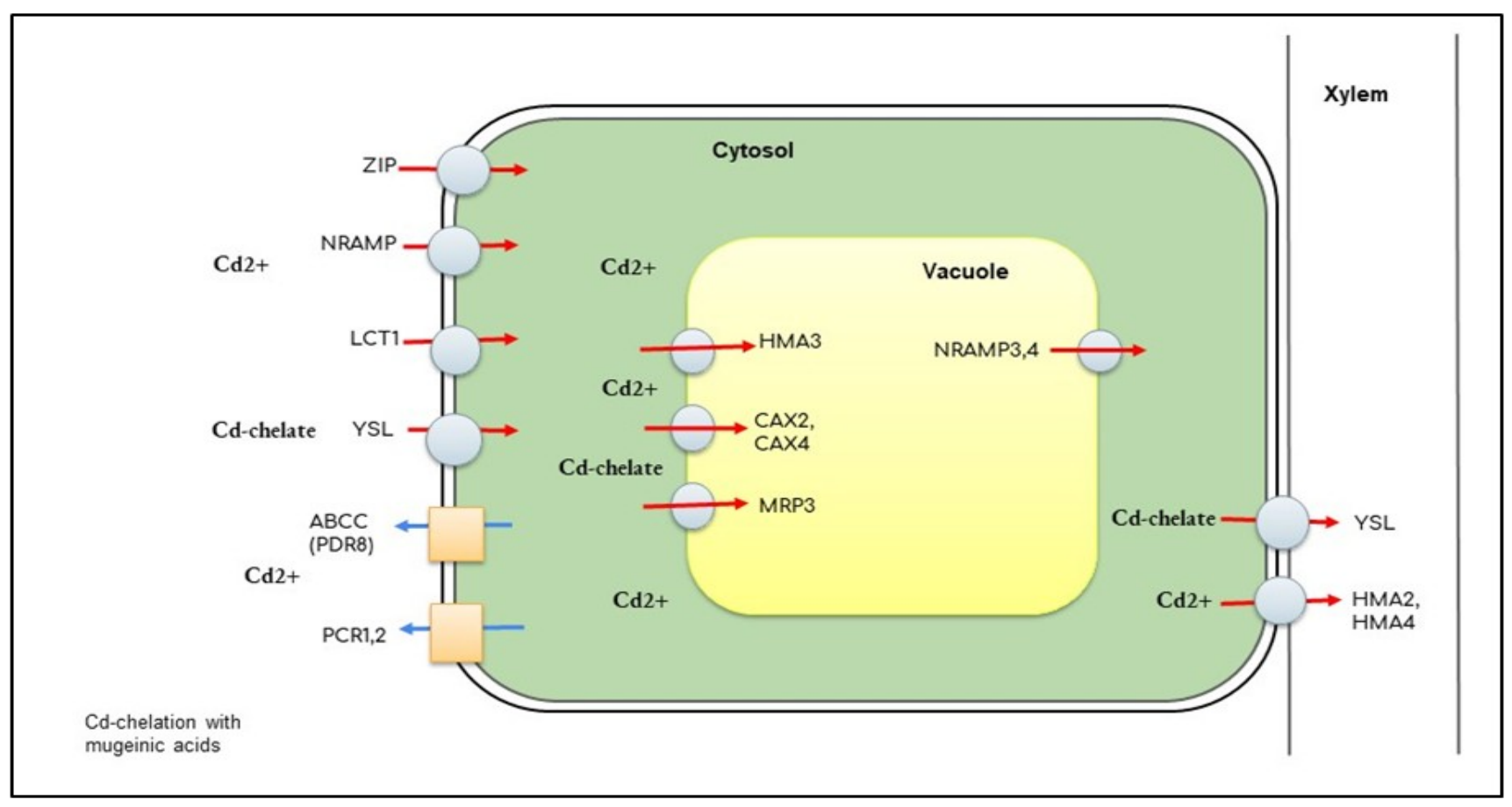

Fig. 3. Schematic representation of different transporter proteins involved in Cd uptake in plants. Red and blue arrows show inward and outward movement of $\mathrm{Cd}$.

synthesised. This hybrid showed a better adsorption efficiency of $\mathrm{Pb}$ (II) and $\mathrm{Cd}$ (II) by more than $50 \%$, as compared to $\mathrm{ZnO}$ and $\mathrm{TiO}_{2}$ individually (13).

Nanogel: These are ionic and non-ionic hydrogels of nano size made up of polymeric chains (104). NGs are more porous with higher water content (70-90\% of the entire structure) and has better load bearing capacity. Chitosan and alginates are commonly used interpenetrated network (IPN) and well known for better stimuli-responsiveness (13).

It is very true that benefits of NPs usage in plant sciences has not been fully explored due to inadequate knowledge of their exact mode of action. Success of nanotechnology depends on the comprehensive knowledge of their bioavailability, uptake and accumulation in plants with simultaneous analysis of their negative impact on plant metabolism and growth. Uptake of NPs by plants is quite unpredictable as it depends on the coordination of multiple factors involving physical features of NPs, way of application and various soil parameters such as soil microbiota, organic matter, water retention capacity and soil texture (16). The route of administration of NPs has great impact on NP availability and uptake capacity of plants. Manufactured NPs are preferably taken up either by roots or the leaves as root exudates facilitate NP adhesion followed by NP internalization on root surface (105). Normally after getting accumulated in cell walls NPs form complex with HM to restrict its bioavailability for plants (11). Soil $\mathrm{pH}$ is one of the most important criteria that regulate the interactions of NPs and HM and its mobility. This is evident from the studies of few workers where $\mathrm{pH}$ was found to influence the charge of the nZVI and its surface protonation that interfere its uptake and further interaction with the metals (106). Adsorption capacity of CNTs was also affected by $\mathrm{pH}$ that alters the potential difference between CNT surface and the ions.

\section{Role of NP in Cd uptake and ROS mitigation}

NP has been successfully applied to reduce bioavailability of heavy metals. Use of $\mathrm{Fe}_{3} \mathrm{O}_{4} \mathrm{NPs}$ was proven to be beneficial for immobilization of $\mathrm{Cd}$ in rice (107). After 3 years of through field study, the role of MPTS nano silica (mercapto functionalized nano silica) in the reduction of bioavailability and leaching effect of $\mathrm{Cd}$ in wheat grain have been established (108). Cd contaminated agricultural soil augmented with nano silica was found to be effective enough for long term $\mathrm{Cd}$ stabilization. Moreover, it was reported that hydroxyapetite NP dependent $\mathrm{Cd}$ immobilization was attributed to the rise in soil $\mathrm{pH}$ due to the release of phosphate in soil (109). Nanozero valent iron was found to be good enough in restricting Cd uptake by inhibiting the expression of various iron transporters in rice exposed to moderate $(10 \mu \mathrm{M}) \mathrm{Cd}$ toxicity (110). In a recent study, Cd uptake was withheld due to the suppression of three $\mathrm{Cd}$ transporter genes OsLCT1, OsHMA2 and OsHMA3 in Cd stressed rice co treated with different concentration of biofabricated iron NP (111).

NP triggers metabolic pathways related to ROS clearance under HM stress (102) to nullify the yield loss. ROS is an unwanted product of oxidative metabolism which in optimum concentrations acts as signalling molecule but has detrimental effect on biomolecules under excess accumulation. DNA damage, lipid peroxidation, protein degradation, membrane damage are common attributes of ROS induced oxidative stress. Photosynthetic efficiency is highly susceptible to heavy metal induced ROS production. Recent study (111) has established the 
antioxidant capacity of biofabricated (biogenic, eco friendly, less toxic) iron NP applied against Cd treated rice plant. Maximum increase in antioxidant enzymes (CAT- 32\%, POD- 48\%, SOD- 32\%) with simultaneous decrease in $\mathrm{ROS}\left(\mathrm{H}_{2} \mathrm{O}_{2^{-}}-54 \%\right)$ was recorded in $\mathrm{Cd}$ and drought stressed rice seedling with concurrent use of IONP (100 mg/kg soil) and chemically synthesised hydrogel NP. In another study, co-application of $10 \mu \mathrm{M} \mathrm{Cd}$ and $100 \mathrm{mg} / \mathrm{l} \mathrm{nZVI}$ was proven to be highly efficient in lowering ROS $\left(\mathrm{H}_{2} \mathrm{O}_{2}\right)$ formation in 17 days old rice seedling both in root $(27.92 \%)$ and shoot $(14.15 \%)$ with respect to untreated ones (110). They also reported confirmatory visual evidence of ROS reduction via ROS imaging by confocal microscopy. Nanoceria, a family of cerium oxide NPs was found to be an effective ROS scavenger in isolated chloroplast. Antioxidants capacity of nanoceria (CNPs) is based on the redox behaviour of $\mathrm{Ce}$ and its ability to shift oxidation states between $\mathrm{Ce}^{3+}$ and $\mathrm{Ce}^{4+}$ has already been confirmed (112) in green alga Pseudokirchneriella subcapitata. Though there are contradictory reports regarding nanoceria mediated ROS production, but the toxicity deciding factor is the $\mathrm{Ce}^{3+} / \mathrm{Ce}^{4+}$ ratio at the particle surface. Under higher ratio of $\mathrm{Ce}^{3+} / \mathrm{Ce}^{4+}$, nanoceria mimics SOD activity resulting hydrogen peroxide accumulation followed by impaired growth, while lower ratio facilitates catalase activity reducing ROS accumulation. Study revealed ROS scavenging potential of nanoceria inside in vitro chloroplast of Arabidopsis thaliana under excess light, heat and chilling stress (113). Poly acrylic acid nanoceria with low $\mathrm{Ce}^{3+} / \mathrm{Ce}^{4+}$ ratio not only reduced ROS production in leaf by $52 \%$ but also enhanced photosynthetic efficiency in terms of quantum yield and $\mathrm{CO}_{2}$ assimilation rate in $A$. thaliana.

\section{Nanoparticles mediated Cd toxicity amelioration}

NPs serve to mitigate toxicity, enhance plant growth and offer versatile means of $\mathrm{Cd}$ immobilization of contaminated soil. Inorganic NPs (Ag, Se, $\mathrm{Au}, \mathrm{Ce}, \mathrm{Fe}$, $\mathrm{Ti}, \mathrm{Zn}$ ) are most effective due to their unique bioactivities in nanoforms. Fig. 4 depicts different modes of NP administration on plants.

\section{Titanium oxide NPs}

$\mathrm{TiO}_{2}$ NPs could serve as a potential tool for agriculturally important crops. Recently use of $\mathrm{nTiO}_{2}$ in plant growth and abiotic stress tolerance is under thorough scrutinization. Due to its large surface area, high adhesiveness, $\mathrm{TiO}_{2} \mathrm{NP}$ is successfully used in agricultural field. A greenhouse experiment was carried out (114) to assess the impact of $\mathrm{TiO}_{2}$ NPs on salinity stressed Dracocephalum moldavica L. 100 $\mathrm{mg} / \mathrm{l} \mathrm{TiO}_{2} \mathrm{NP}$ ameliorated detrimental effects of 100 $\mathrm{mM} \mathrm{NaCl}$ and improved agronomic parameters by upregulating SOD and APX activities. Further research indicated positive effects of $\mathrm{TiO}_{2}$ nanoparticles on Cd stressed cowpea plants (115) where soil augmentation with $\mathrm{nTiO}_{2}(100 \mathrm{mg} / \mathrm{kg})$ upregulated antioxidative enzyme activity (APX and CAT) with simultaneous reduction of membrane damage. This study revealed that $\mathrm{TiO}_{2}$ could be used as a green alternative to ameliorate the $\mathrm{Cd}$ toxicity in cowpea plants. The positive impact of $\mathrm{TiO}_{2} \mathrm{NP}$ on root length, hormone concentration, antioxidant enzyme activity of $\mathrm{Cd}$ stressed rice indicated the healing capacity of this NP though seedling biomass remains unaltered (116). Successful inhibition of $\mathrm{Cd}$ absorption by foliar spray of $\mathrm{TiO}_{2} \mathrm{NP}$ in maize grown in moderate to higher soil Cd concentration (100-250 $\mathrm{mg} / \mathrm{l}$ ) was also documented (117). Moreover SOD and GST activity was elicited which corresponds to increase in various metabolic routes to mitigate $\mathrm{Cd}$ toxicity of maize.

\section{Selenium NPs}

Being an essential trace element Selenium NPs are easily taken up by plants. Its administration facilitates reduction of cd contamination in cabbage (Brassica rapa) and lettuce (Lactuca sativa L.). Multifaceted benefit of Se NPs in Cd stressed Brassica juncea includes enhanced uptake of important minerals ( $\mathrm{Mn}$ and $\mathrm{Mg}$ ), increase in relative water content (RWC) and activities of anti oxidative enzymes (118). Moreover, elevated proline accumulation, over expression of glutathione reductase (GR) and peroxidase (POX) with subsequent decrease in ethylene, relieved the $\mathrm{Cd}$ induced oxidative stress in wheat plant (119). Actually, Se is incorporated as selenocysteine which is a vital amino acid in the active centre of selenoprotein that participates in oxidation reduction reactions (120). Similar observation was reported in pepper plant where Se NP treatment improved the quality and quantity of the pepper fruits and up regulated anti oxidative defense machinery against Cd stress.

\section{Cerium Oxide NPs}

Literature revealed the effectiveness of low concentration of $\mathrm{CeO}_{2} \mathrm{NPs}$ on plant growth due to its higher porosity and better catalytic activity (121). It has been reported that $\mathrm{CeO}_{2}$ NPs $(100 \mathrm{mg} / \mathrm{kg})$ enhanced the rate of photosynthesis in soybeans while $500 \mathrm{mg} / \mathrm{kg} \mathrm{CeO}_{2}$-NPs lowered the same by $36 \%$ (122). $\mathrm{CeO}_{2}$ NPs dependent reduction (70\%) of $\mathrm{Cd}$ translocation was proven in soybean seedlings (123) grown in hydroponics with co-application of $1.0 \mathrm{mg} \mathrm{l}^{-1}$ $\mathrm{Cd}^{2+}+100 \mathrm{mg} \mathrm{l}^{-1} \mathrm{CeO}_{2} \mathrm{NP}$. Over secretion of root exudates was observed due to the co-presence of $\mathrm{Cd}$ and $\mathrm{CeO}_{2}$ NPs which enhanced the $\mathrm{CeO}_{2} \mathrm{NP}$ dissolution due to the alteration in the chemical environment of the plant rhizosphere. Foliar spray of $\mathrm{CeO}_{2} \quad \mathrm{NPs}(200 \mathrm{mg} / \mathrm{l})$ significantly elicited antioxidative detoxification capacity in hydroponically grown rice treated with $\mathrm{CdCl}_{2} 50 \mu \mathrm{M}$ and restricted the uptake of $\mathrm{Cd}$ (124). Several contradictory reports are available regarding the effect of $\mathrm{CeO}_{2} \mathrm{NP}$ in metal accumulation in plant. No significant impact of $\mathrm{CeO}_{2} \mathrm{NPs}(500 \mathrm{mg} / \mathrm{kg})$ on $\mathrm{Cd}$ accumulation in soybeans cultivated in $\mathrm{Cd}$ polluted soil $(1.0 \mathrm{mg} / \mathrm{kg})$ was noted; rather uptake of Ce in plant was observed (125). This might be due to the combined application of $\mathrm{Cd}$ and $\mathrm{CeO}_{2} \mathrm{NPs}$ that influenced root apoplastic pathway.

\section{Silicon dioxide NPs}

As Silicon triggers stress tolerance potential in plants, $\mathrm{SiO}_{2}$ is one of the most famous nanomaterials being used in environmental remediation. Being second most abundant soil element, Si confers tolerance to 
plants against abiotic and biotic stress. Silicon NP

(SiNP) mediated mitigation of $\mathrm{Cd}$ contaminated rice electrolytic damage (129). Use of Si NP has gained focus in fertilizer formulations due to considerable

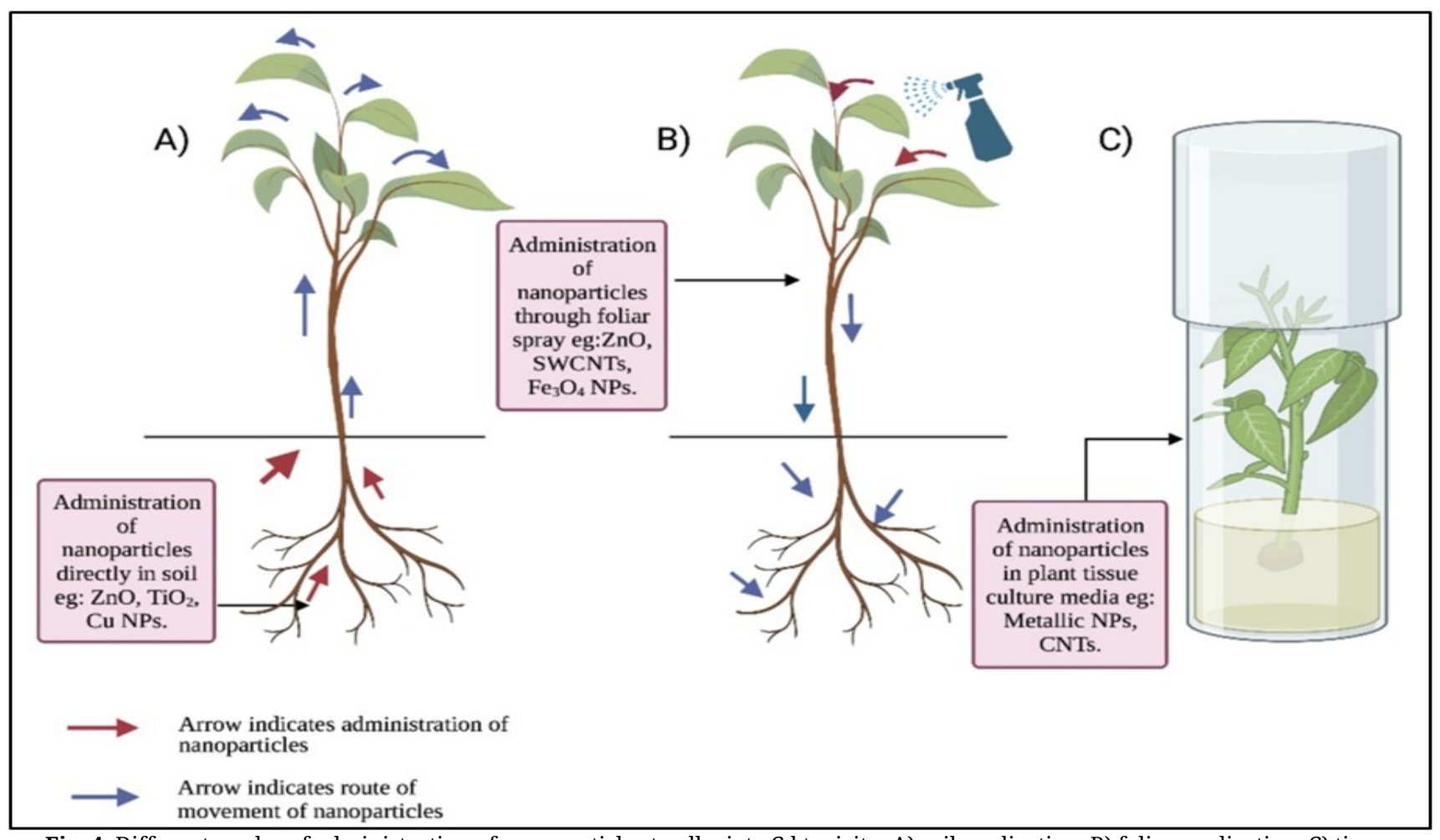

Fig. 4. Different modes of administration of nanoparticles to alleviate Cd toxicity. A) soil application, B) foliar application, C) tissue culture application.

plants is of paramount interest since the last decades. Recent research indicated Si dependent reduction of soil to plant $\mathrm{Cd}$ translocation via upregulation of vacuolar transporter OVP1 which was positively correlated with low grain $\mathrm{Cd}$ accumulation in two rice cultivars (53). Few workers (11) observed positive effects of silica NPs on rice cells treated with $\mathrm{Cd}$ in suspension culture. Result revealed that $\mathrm{Cd}$ toxicity amelioration capacity of SiNP was size dependent and indirectly proportional to its effectiveness. The average $\mathrm{Cd}^{2+}$ influx in rice cells treated with SiNPs (19 nM, $48 \mathrm{nM}$ and $202 \mathrm{nM}$ ) decreased by 15.7-, 11.1- and 4.6- fold respectively on using noninvasive micro test technology. SiNPs down regulated the expression of $\mathrm{Cd}$ uptake and transporter gene - OsLCT1 and OsNramp5, but elevated the expression of OsHMA3- gene involved in Cd transport into the vacuole and OsLsi1 - gene involved in Si uptake. A hydroponic experiment was designed with foliar application of $2.5 \mathrm{mM}$ nano-silica to reduce $\mathrm{Cd}$ stress in rice seedlings which suffered from compromised growth and mineral deficiency (Mg, Fe, Zn) (126). Nano-Si application was found to be beneficial for growth enhancement and mineral uptake of rice seedlings with simultaneous significant increase in GSH content imparting better defense against $\mathrm{Cd}$. It also helped to lower the rate of $\mathrm{Cd}$ translocation from roots to shoot. Foliar application of Si NPs was also found to be quite capable in minimizing $\mathrm{Cd}$ accumulation in rice grain $(127,128)$ and quality enhancement. Ali and his team reported Si NP dependent growth restoration of $\mathrm{Cd}$ treated wheat seedlings by increase in biomass, pigment content and restricting grain $\mathrm{Cd}$ concentration and enhanced bioavailability than conventional $\mathrm{Si}$ fertilizers (11).

\section{Nano-hydroxyapatite (nHAP) NPs}

Application of nHAP is not only cost-effective but also eco-friendly and highly efficient for $\mathrm{HM}$ immobilization in contaminated soil due to their better adsorption efficiency, low water solubility, high stability in redox reactions and good cytocompatibility. The nHAP works by exchanging the $\mathrm{Ca}^{2+}$ ions present on its surface with the heavy metal ions present in the soil and thereby decreasing the transport of heavy metals to the plants. Application of $30 \mathrm{~g} / \mathrm{kg} \mathrm{nHAP}$ in $10 \mathrm{mgkg}^{-1}$ Cd-treated Brassica chinensis, showed a prominent decrease in Cd shoot translocation (62.36\%) with increase in chlorophyll and vitamin $\mathrm{C}$ content was recorded followed by minimization of MDA content and elevation in anti oxidative enzymes activities (SOD, CAT and POD) (130). Positive effects of nHAP on $\mathrm{Cd}$ and $\mathrm{Pb}$ co-contaminated soil, was evident from reduction of water-soluble $\mathrm{Pb}$ and $\mathrm{Cd}$ by $72 \%$ and $90 \%$ respectively (131). Bioavailability of $\mathrm{Pb}$ and $\mathrm{Cd}$ also decreased by $12.5-27.5 \%$ and $17.7-34.6 \%$ respectively. By releasing phosphate and increasing soil $\mathrm{pH}$, nHAP reduces the phytoavailability of HM in the contaminated soil (109). An increase in the pH of the Cd-contaminated soil $(10 \mathrm{mg} / \mathrm{kg})$ was noted after the administration of nHAP $(0.2 \%, 0.5 \%$ and $1 \%)$ (132).

\section{Iron NPs}

Iron has pivotal importance in the physiochemical processes of plants. It is essential in photosynthesis 
for synthesis of certain chlorophyll-protein complexes in chloroplasts, respiration, cell's metabolism and co-factor of enzymes (112). Iron salt application has proved to be effective in enhancing the carbon and nitrogen assimilation in rice plants and also improving the yield $(133,134)$. Iron NPs act as efficient adsorbents due to their structural uniqueness, electronic features, large surface area, fast reaction speed and strong reduction ability (135). The various ways explored by nano iron for amelioration of heavy metal toxicity is by adsorption of heavy metals on its surface, promoting the formation of root surface iron film, activating the antioxidative defense mechanisms and by detoxifying the ROS. But, the tendency to aggregate and react quickly with the non-target compound reduces the stability of iron NPs (136). The individual and joint effects of citrate-coated magnetite NPs on the bioaccumulation and toxicity of $\mathrm{Cd}^{2+}$ and $\mathrm{Cr}^{6+}$ on wheat plants was studied for seven days by LopezLuna and team (137). The parameters studied were rate of germination, rooting and shooting and metal uptake. A 50\% decrease in the root length of wheat at $2.7 \mathrm{mg} \mathrm{Cd}{ }^{2+} \mathrm{kg}^{-1}$ and $5.6 \mathrm{mg} \mathrm{Cr}{ }^{6+} \mathrm{kg}^{-1}$ was observed. However, the root length of plants was found to increase by $25 \%$ and $50 \%$ when magnetite NPs (1000 $\mathrm{mg} \mathrm{kg}^{-1}$ ) was added. A similar and non-interactive joint action of $\mathrm{Cd}^{2+}$ and $\mathrm{Cr}^{6+}$ was observed, but they strongly inhibited the growth of wheat seedlings. External administration of magnetite NPs diminished the accumulation of cadmium and chromium in the vegetable tissues and also alleviated heavy metal toxicity. Few workers scrutinized different effects of nZVI to alleviate Cd toxicity (138-140). $500 \mathrm{mgkg}^{-1}$ nZVI acts as growth promoter and elevates photosynthesis in Arabidopsis. OsCAX 4 was found to be upregulated in roots on administering nZVI but was down regulated in shoot. The soil exchangeable Cd decreased by $74.04 \%$ on nZVI treatment. It also helped to increase the proline levels and decreased ROS levels by increasing the levels of anti-oxidative enzymes to combat the abiotic Cd stress in the plants. nZVI unregulated the level of NPSH and restricted $\mathrm{Cd}$ translocation in the roots through chelation. Soil treatment and foliar spraying of $\mathrm{Fe}_{2} \mathrm{O}_{3}$ NPs was found to be quite effective in lowering electrolytic leakage and grain accumulation of $\mathrm{Cd}$ stressed wheat with simultaneous increase in SOD, POX activities and growth parameters (141). Application of starchstabilized nZVI particles could improve the phytoextraction efficiency of ramie (142). Starchstabilized nZVI particle $(100,500,1000 \mathrm{mg} / \mathrm{kg})$ was added to the contaminated sediment before plantation which elevated Cd uptake in the roots (16$50 \%)$, stems (29-52\%) and leaves (31-73\%). Oxidative injury of Cd-stressed ramie was withdrawn by low level $(100 \mathrm{mg} / \mathrm{kg})$ of nZVI administration, while the growth of plant was affected under higher nZVI concentration. This indicates that the choice of effective concentration is a prerequisite for phytoremedial success of nZVI. In rice plants exposed to Cd stress, external administration of nZVI suppressed the gene expression of iron transporters (IRT1, IRT2, YSL2 and YSL15) involved in Cd and Fe uptake (110). Moreover, the genes - OSVIT1 and OSCAX4 were over-expressed resulting in $\mathrm{Cd}$ sequestration in vacuoles which was further facilitated due to upregulation of phytochelatin synthesis. Though studies have reported that high doses of iron NPs are phytotoxic for rice growth in hydroponic system $(143,144)$ but lower doses of nZVI enhanced seedling (14 days old) vigour in rice cv. Gobindobhog (145). Recent work has suggested the important and commercial role of nZVI as growth and yield enhancer in field grown rice (146). Plants germinated from nanoprimed seeds were reported to have better vitality regarding various agronomic traits (biomass, tiller numbers, broader leaves, photosynthetic efficiencies). Low dosage of nZVI (10 $\mathrm{mg} / \mathrm{l}$ ) was confirmed having no genotoxic effect also.

\section{Zinc Oxide NPs}

Zinc is an essential micronutrient which plays an integral role in various metabolic processes such as biosynthesis of carotenoids and enhancing the photosynthetic apparatus of the plants. Higher absorption efficiency makes ZnO suitable for soil and water decontamination, but due to its agglomeration at higher concentration it is tough to separate and recover $(147,148)$. Zinc oxide NP (ZnONP) was found to be very effective in mitigating $\mathrm{Cd}$ toxicity when externally applied to Cd-contaminated rice fields (1.0 $\mathrm{mgkg}^{-1}$, $2.5 \mathrm{mgkg}^{-1}$, $5.0 \mathrm{mgkg}^{-1}$ ). The biomass of rice plant was found to increase by $13-22 \%$ and $25-43 \%$ in the rice fields exposed to $2.5 \mathrm{mgkg}^{-1}$ and $5.0 \mathrm{mgkg}^{-1} \mathrm{Cd}$ respectively (149). Cd toxicity amelioration with 50 $\mathrm{mg} / \mathrm{l} \mathrm{ZnO} \mathrm{NP}$ in various concentration of Cd stressed $(0.4,0.6,0.8 \mathrm{mM})$ tomato was reported (150). $\mathrm{Cd}$ induced oxidative burst was relieved by ZnO NPs, which is evident from sharp drop in endogenous $\mathrm{H}_{2} \mathrm{O}_{2}$ and superoxide content generation with increase in growth parameters (height, biomass), photosynthetic rates, protein content, nitrate reductase and carbonic anhydrase activities. A study (151) exposed the Leucaena leucocephala to different concentrations of $\mathrm{Pb}\left(\mathrm{NO}_{3}\right)_{2}-\left(0,25,50,75,100,150\right.$ and $\left.200 \mathrm{mgl}^{-1}\right)$ and $\mathrm{CdCl}_{2}-\left(0,10,20,30,40,50,75\right.$ and $\left.100 \mathrm{mgl}^{-1}\right)$ in a hydroponic medium. Seven combinations of ZnO NPs and two heavy metals- $\mathrm{Cd}$ and $\mathrm{Pb}$ was applied, where ZnO NP causes a significant increase in chlorophyll content and total soluble protein content with sharp drop in the malondialdehyde (MDA) content. Activities of superoxide dismutase (SOD), catalase (CAT) and peroxidase (POX) were found to be uplifted. It was revealed that positive effect of combined treatment of organic amendments and $\mathrm{ZnO}$ NPs foliar spray $(100,200 \mathrm{mg} / \mathrm{l})$ which was effective enough to increase biomass, yield, pigment content and antioxidative enzyme activities in $\mathrm{Cd}$ treated wheat (152). Recent workers have suggested that combination of biochar and ZnO NP was found to be more successful than individual application to deal with HM (Cd) toxicity $(144,152,153)$. ZnO has enough potential to overcome combined water and Cd stress in wheat by minimizing oxidative damage and bioavailable $\mathrm{Cd}$ content in water deficit soil.

\section{Carbon nanotubes(CNTs) and Modified Carbon Black(MCB)}

Remarkable use of CNTs in nano biosciences is attributed to its light weight, unique electrical, mechanical features, chemical resistance, thermal 
stability and higher durability (112). The effect of carbon nanotubes to reduce Cd toxicity was studied in Spartina alterniflora (154). The experimental design consisted of two Cd concentrations (50 and 200 $\mathrm{mgkg}^{-1}$ ) with two CNT levels (800 and $2400 \mathrm{mgkg}^{-1}$ ). CNTs reduced $\mathrm{Cd}$ stress $\left(200 \mathrm{mgkg}^{-1}\right)$ by improving shoot growth and retrieving the water content. The effect of 100, 500, 1000 and $5000 \mathrm{mg} / \mathrm{kg}$ of Multiwalled Carbon Nanotubes (MWCNTS) was investigated on Boehmeria nivea L. seedlings grown in Cd-polluted water sediments (155). Results indicated that $500 \mathrm{mg} / \mathrm{kg}$ of MWCNTS successfully alleviated Cd-induced oxidative injuries by growth promotion and up regulating anti oxidative defense response. But poor solubility of CNT in aqueous media or organic solvents is the main constrain of its maximum use (156). The effects of MCB on $5 \mathrm{mgkg}^{-1}$ of Cd-contaminated soil of Lolium multiform (Rye grass) and Beta vulgaris (Chard), was studied by Cheng and his colleagues (157). Positive results of MCB were reported which indicated increase in dry biomass of shoots of ryegrass and chard by 1.07 and 1.05 times respectively with elevated activity of urease and catalase after 25 days of incubation. In the control set, a decrease in the nitrogen-functional bacteria like Nitrososphaera was reported. MCB helped to increase the microflora in the soil and reduced the bioavailability of heavy metals in the soil. This promoted plant growth, by increasing nitrogen concentration in the soil.

\section{Conclusion and future prospects}

Uninterrupted advancement of technology, has introduced an era of nano bioscience, by the virtue of which several types of smartly designed NPs are available in the market. The matter of concern is the proper determination of nanoparticles' interaction with plants to explore their ultimate benefit. Considerable effort has been made to enhance the phytoremediation efficiency by combining different strategies or modifying the NPs. Engineered NPs are also extensively utilized for quality crop production, as growth elicitor, nanopesticides, phytoremediating soil and water, nanofertilizers. Application of nanoparticles in plants has been an intricate area of investigation and data published over that last 10 years have been befitting evidence to this fact. Though there are numerous review articles available on nanoparticle-plant interaction, to our best knowledge, this article is unique being the first comprehensive review on NP mediated alleviation of cadmium inflicted stress in plants. However, regarding limitations, this review article does not discuss the synthesis and characterization of the various NP that have been employed to mitigate $\mathrm{Cd}$ stress in plants. Rather, this work mainly highlights the biological aspect of NP application and stress alleviation in plants. The ambiguity of success of NPs in growth promotion, HM remediation depends on various criteria, such as; exposure level, mode of application, optimum concentration. The mode of administration of NPs needs to be addressed more thoroughly in future research. Application of NPs in combination with other materials is a more promising aspect of plant growth booster and immobilization of HM. More advanced research work from various applied aspects is needed to understand the long-term performance of NPs in heavy metal decontamination purpose. It is true that the huge production cost behind NPs is one of the reasons behind their limited use. Therefore, we can suggest and look forward for the synthesis of eco-friendly and economic NPs by integrating the principles of green nanotechnology.

\section{Acknowledgements}

All the authors would like to acknowledge their respective institutions for the support and encouragement. For financial aid $\mathrm{SP}^{1}$ is thankful to West Bengal DST funded major R \& D project [Sanction No:1925(Sanc.)/STBT-11012(15)/18/2019-ST SEC]. All figures are created with biorender.com.

\section{Authors' contributions}

SC made the basic framework. SP $^{1}$ supervised, curated and drafted the manuscript. $\mathrm{SP}^{2}$ conceived the main idea and scrutinized the manuscript. All authors read and approved the final manuscript.

\section{Conflict of interests}

Authors do not have any conflict of interest to declare.

\section{References}

1. Chellaiah ER. Cadmium (heavy metals) bioremediation by Pseudomonas aeruginosa: a mini-review. Appl Water Sci. 2018;8:154. https://doi.org/10.1007/s13201- 018-0796-5

2. Qiao K, Wang F, Liang S, Wang H, Hu Z, Chai T. Improved Cd, $\mathrm{Zn}$ and $\mathrm{Mn}$ tolerance and reduced $\mathrm{Cd}$ accumulation in grains with wheat based cell number regulator TaCNR2. Sci Rep. 2019;9(1):870. https://doi.org/10.1038/s41598-018-37352-6

3. Haider FU, Liqun C, Coulter JA, Cheema SA, Wu J, Zhang $\mathrm{R}$, Wenjun M, Farooq M. 2021. Cadmium toxicity in plants: Impacts and remediation strategies. Ecotoxicology and Environmental Safety. 2021:211 https://doi.org/10.1016/j.ecoenv.2020.111887

4. Kubier A, Wilkin RT, Pichler T. Cadmium in soils and groundwater: a review. Appl Geochem. 2019;108:1-16. https://doi.org/10.1016/j.apgeochem.2019.104388

5. Khan MA,Khan S, Khan A, Alam M. Soil contamination with cadmium consequences and remediation using organic amendments. Science of the total environment. 2017;601:5911605. https://doi.org/10.1016/j.scitotenv.2017.06.030

6. Jali P, PradhanC, Das AB. Effects of cadmium toxicity in plants: a review article. Sch Acad J Biosci. 2016;4:1074-81. https://doi.org/10.21276/ sajb.2016.4.12.3

7. Genchi G, Sinicropi MS, Lauria G, Carocci A, Catalano A. The Effects of Cadmium Toxicity. Int J Environ Res. Public Health. 2020;17(11):3782. https://doi.org/10.3390/ijerph17113782

8. Shi Z, Carey M, Meharg C, Williams PN, Signes-Pastor AJ, Triwardhani EA, PandianganFI, Campbell K, Elliott C, Marwa $\mathrm{EM}$ et al. Rice grain cadmium concentrations in the global supply-chain. $\quad$ Expo Health. 2020;12:869-76. https://doi.org/10.1007/s12403-020-00349-6

9. Tinkov AA, Gritsenko VA, Skalnaya MG, Cherkasov SV, Aaseth J, Skalny AV. Gut as a target for cadmium toxicity. Environ Pollut. https://doi.org/10.1016/j.envpol.2017.12.114 2018;235:429-34.

10. Nishijo M, Nakagawa H, Suwazono $\mathrm{Y}$, Nogawa K, Kido T. Causes of death in patients with itai- itai disease suffering from severe chronic cadmium poisoning: a nested case- control analysis of a follow up study in Japan. BMJ open. 2017;7:e015694. https://doi.org/10.1136/bmjopen-2016-015694 
11. Cui J, Liu T, Li F, Yi J, Liu C, Yu H. Silica nanoparticles alleviate cadmium toxicity in rice cells: Mechanisms and size effects. $\begin{array}{lll}\text { Environmental } & \text { 2017;228:363-69. }\end{array}$ https://doi.org/10.1016/j.envpol.2017.05.014

12. Astm E2456 - 06. Standard Terminol. Relat. to Nanotechnol. 2012;6:5-6. https://doi.org/10.1520/E2456-06R12

13. Sanzari I, Leone A, Ambrosone A. Nanotechnology in Plant Science: To Make a Long Story Short. Front. Bioeng. Biotechnol. 2019;7:120. https://doi.org/10.3389/fbioe.2019.00120

14. Khan ZS, Rizwan M, Hafeez M, Ali S, Javed MR, Adrees M. The accumulation of cadmium in wheat (Triticum aestivum) as influenced by zinc oxide nanoparticles and soil moisture conditions. Environ Sci Pollut Res Int. 2019;26:19859-70. https://doi.org/10.1007/s11356-019-05333-5

15. Verma SK, Das AK, Patel MK, Shah A, Kumar V, Gantait S. Engineered nanomaterials for plant growth and development: A perspective analysis. Science of the Total Environment. 2018;630:1413-35.

https://doi.org/10.1016/j.scitotenv.2018.02.313

16. Hussain B, Lin Q, Hamid Y, Sanaullah M, Di L, Hashmi MLUR, Khan MB, He Z, Yang X Foliage application of selenium and silicon nanoparticles alleviates $\mathrm{Cd}$ and $\mathrm{Pb}$ toxicity in rice (Oryza sativa L.) Sci Total Environ. 2020;712:136497.https://doi.org/10.1016/j.scitotenv.2020.136497

17. Li M, Zhang P, Adeel M, Guo Z, Chetwynd AJ, Ma C, Bai T, Hao $\mathrm{Y}$, Rui Y. Physiological impacts of zero valent iron, $\mathrm{Fe}_{3} \mathrm{O}_{4}$ and $\mathrm{Fe}_{2} \mathrm{O}_{3}$ nanoparticles in rice plants and their potential as $\mathrm{Fe}$ fertilizers. Environ $\quad$ Pollut. 2021;269:116134. https://doi.org/10.1016/j.envpol.2020.116134

18. Chhipa H. Nanofertilizers and nanopesticides for agriculture. Environmental Chemistry Letters. 2017;15(1):15-22. https://doi.org/10.1007/s10311-016-0600-4

19. Adeel M, Farooq T, White J, Hao Y, He Z, Rui Y. Carbon-based nanomaterials suppress Tobacco Mosaic Virus (TMV) infection and induce resistance in Nicotiana benthamiana. J Hazard Mater.

https://doi.org/10.1016/j.jhazmat.2020.124167

20. Lombi E, Donner E, Dusinska M, Wickson F. A One Health approach to managing the applications and implications of nanotechnologies in agriculture. Nat Nanotechnol. 2019;14, 523-31._https://doi.org/10.1038/s41565-019-0460-8

21. Kubier A and Pichler T. Cadmium in groundwater- a synopsis based on a large hydrogeochemical data set. Sci Total Environ. 2019;689:831-42. https://doi.org/10.1016/j.scitotenv.2019.06.499

22. Bigalke M, Ulrich A, Rehmus A, Keller A. Accumulation of cadmium and uranium in arable soils in Switzerland. Environ Pollut.

https://doi.org/10.1016/j.envpol.2016.11.035

23. Khan MA, Khan S, Khan A, Alam M. Soil contamination with cadmium, consequences and remediation using organic amendments. Sci Total Environ. 2017;601-02:1591-1605. https://doi.org/10.1016/j.scitotenv.2017.06.030

24. Satarug S. Cadmium sources and toxicity. Toxics. 2019;7(2):25. https://doi.org/10.3390/toxics7020025

25. Song Y, Jin L, Wang X. Cadmium absorption and transportation pathways in plants. Int J Phytoremediation. 2017;19(2):13341.https://doi.org/10.1080/15226514.2016.1207598

26. Nikolić N, Zorić L, Cvetković I, Pajević S, Borišev M, Orlović S, Pilipović A. Assessment of cadmium tolerance and phytoextraction ability in young Populus deltoides L. and Populus $\mathrm{x}$ euramericana plants through morpho-anatomical and physiological responses to growth in cadmium enriched soil. iforest Biogeoscience and Forestry. 2017;10(3):635-44. https://doi.org/10.3832/ifor2165-010

27. Li $\mathrm{Z}, \mathrm{Wu} \mathrm{L}$, Luo $\mathrm{Y}$, Christie P. Changes in metal mobility assessed by EDTA kinetic extraction in three polluted soils after repeated phytoremediation using a cadmium/zinc hyperaccumulator. Chemosphere. 2018;194:432-40. https://doi.org/10.1016/j.chemosphere.2017.12.005

28. Sarwar N, Saifulla, Mahi SS, Zia MH, Naeem A, Bibi S, Farid G. Role of mineral nutrition in minimizing cadmium accumulation by plants. J Sci Food Agric. 2010;90(6):925-37. https://doi.org/10.1002/jsfa.3916

29. Abbas T, Rizwan M, Ali S, Adrees M, Zia-ur-Rehman, M, Qayyum, M.F, Ok, YS, Murtaza, G. Effect of biochar on alleviation of cadmium toxicity in wheat (Triticum aestivum L.) grown on Cd-contaminated saline soil. Environ Sci Pollut Res. 2017;25:25668-80. https://doi.org/10.1007/s11356-017-8987-4.
30. Rizwan M, Ali S, Adrees M, Ibrahim M, Tsang DC, Zia-urRehman M, Zahir ZA, Tack FM, Ok YS. A critical review on effects, tolerance mechanisms and management of cadmium in vegetables. Chemosphere. 2017;182:90-105. https://doi.org/10.1016/j.chemosphere.2017.05.013

31. Raza A, Habib M, Kakavand SN, Zahid Z, Zahra N, Sharif R, Hasanuzzaman M. Phytoremediation of cadmium: physiological, biochemical and molecular mechanisms. Biology. 2020;9:177. https://doi.org/10.3390/biology9070177

32. Kalai T, Bouthour D, Manai J, Ben-Kaab LB, Gouia H. Salicylic acid alleviates the toxicity of cadmium on seedling growth, amylase and phosphatases activity in germinating barley seeds. Arch Agron Soil Sci. 2016;62:892-904.

33. Wang M, Yang Y, Chen WP. Manganese, zinc and $\mathrm{pH}$ affect cadmium accumulation in rice grain under field conditions in Southern China. J Environ Qual. 2018;47(2):306-11. https://doi.org/10.2134/jeq2017.06.0237

34. Abbas T, RizwanM, Ali S, Adrees M, Zia-ur-Rehman M, Qayyum MF, Ok YS, Murtaza G. Effect of biochar on alleviation of cadmium toxicity in wheat (Triticum aestivum L.) grown on Cdcontaminated saline soil. Environ Sci Pollut Res. 2018;25(26):25668-80. https://doi.org/10.1007/s11356-017-89874

35. Jinadasa N, Collins D, Holford P, Milham PJ and Conroy JP. Reactions to cadmium stress in a cadmium- tolerant variety of cabbage (Brassica oleracea L.): Is cadmium tolerance necessarily desirable in food crops?, Environ Sci Pollut Res., 2016;23:5296-306. https://doi.org/10.1007/s11356-015-5779-6

36. Zhang F, Liu M, Li Y, Che Y, Xiao Y. Effects of arbuscular mycorrhizal fungi, biochar and cadmium on the yield and element uptake of Medicago sativa. Sci Toal Environ. 2019;655:1150-58.

https://doi.org/10.1016/j.scitotenv.2018.11.317

37. Kinay A. Effects of cadmium on nicotine, reducing sugars and phenolic contents of Basma tobacco variety. Fresenius Environ Bull. 2018;27:9195-202.

38. Yamaguchi N, Mori S, Baba K, Kaburagi-Yada S, Arao T, Kitajima N, Hokura A, Terada Y. Cadmium distribution in the root tissues of solanaceous plants with contrasting root-toshoot Cd translocation efficiencies. Environ Exp Bot. 2011;71(2):198-206.

https://doi.org/10.1016/j.envexpbot.2010.12.002

39. Dutta S, Mitra M, Agarwal P, Mahapatra K, De S, Sett U, Roy S. Oxidative and genotoxic damages in plants in response to heavy etal stress and maintenance of genomic stability. Plant Signaling and 2018. https://doi.org/10.1080/15592324.2018.1460048

40. Gutsch A, Sergeant K, Keunen E, Prinsen E, Guerriero G, Renaut J, Hausman JeF, Cuypers A. Does long-term cadmium exposure influence the composition of pectic polysaccharides in the cell wall of Medicago sativa stems? BMC Plant Biol. 2019;19:271. https://doi.org/10.1186/s12870-019-1859-y

41. Barman F, Majumdar S, Arzoo SH, Kundu R. Genotypic variation among 20 rice cultivars/landraces in response to Cadmium stress grown locally in West Bengal, India. Plant Physiol Biochem. 2020;148:193-206. https://doi.org/10.1016/j.plaphy.2020.01.019

42. Jalmi SK, Bhagat PK, Verma D, Noryang S, Tayeeba S, Singh K, Sharma D, Sinha AK. Traversing the links between heavy metal stress and plant signaling. Front Plant Sci. 2018;9:12. https://doi.org/10.3389/fpls.2018.00012.PMID:29459874.

43. Majumdar S, Chakraborty B, Kundu R. Comparative analysis of cadmium-induced stress responses by the aromatic and nonaromatic rice genotypes of West Bengal. Environ Sci Pollut Res Int. 2018;25(19):18451-61. https://doi.org/10.1007/s11356-0181966-6

44. Zhao H, Guan J, Liang Q, Zhang X, Hu H, Zhang J. Effect of cadmium stress on growth and physiological characteristics of sassafras seedlings. $\quad$ Sci $\quad$ Rep. 2021. https://doi.org/10.1038/s41598-021-89322-0

45. Rady MM, Elrys AS, Abo El- Maati MF, Desoky EM. Interplaying role of silicon and proline effectively improve salt and cadmium stress tolerance in Phaseolus vulgaris plant. Plant Physiol Biochem. 2019;139:558-68. https://doi.org/10.1016/j.plaphy.2019.04.025.Epub2019

46. Küpper H, Parameswaran A, Leitenmaier B, M. Trtílek, Šetlík I. Cadmium-induced inhibition of photo- synthesis and long-term acclimation to cadmium stress in the hyper-accumulator 
Thlaspi caerulescens, New Phytol. 2007;175(4):655-74. https://doi.org/10.1111/j.1469-8137.2007.02139.x

47. Noor W, Umar S, Mir MY, Shah D, Majeed G, Hafeez S, Yaqoob S, Gulzar A, Kamali AN. Effect of cadmium on growth, photosynthesis and nitrogen metabolism of crop plants. IBM J Res Dev. 2018;18:100-06.

48. Tran TA, Popova LP. Functions and toxicity of cadmium in plants: recent advances and future prospects. Turk J Bot. 2013;37(1):1-13. https://doi.org/10.3906/b0t-1112-16

49. Li S, Yu J, Zhu M, Luan S. Cadmium impairs ion homeostasis by altering $\mathrm{K}+$ and $\mathrm{Ca}+$ channel activities in rice root hair cells Plant Cell Environ. 2012;35(11):1998-2013. https://doi.org/10.1111/j.1365-3040.2012.02532.x

50. Ruta LL, Popa VC, Nicolau I, Danet AF, Iordache V, Neagoe AD, Farcasanu IC. Calcium signaling mediates the response to cadmium toxicity in Saccharomyces cerevisiae cells. FEBS Lett 2014;588 17:3202-12.

51. Sabrine H, Afif H, Mohamed B, Hamadi B, María HM. Effects of cadmium and copper on pollen germination and fruit set in pea (Pisum sativum L.). Sci Aortic. 2010;125:551-55. http://dx.doi.org/10.1016/j.scienta.2010.05.031

52. Moharem M, Elkhatib E, Mesalem M. Remediation of chromium and mercury polluted calcareous soils using nanoparticles: Sorption-desorption kinetics, speciation and fractionation. Environ Res. 2019;170:366-73. https://doi.org/10.1016/j.envres.2018.12.054

53. Cao F, Dai H, Hao PF, Wu F. Silicon regulates the expression of vacuolar $\mathrm{H}^{+}$-pyrophosphatase 1 and decreases cadmium accumulation in rice (Oryza sativa L.). Chemosphere. 2020;240:124907.10.1016/j.chemosphere.2019.124907

54. Srivastava RK, Pandey P, Rajpoot R, Rani A, Dubey RS. Cadmium and lead interactive effects on oxidative stress and antioxidative responses in rice seedlings. Protoplasma. 2014;251(5):1047-65. 10.1007/s00709-014-0614-3

55. Pal R, Kaur R, Rajwar D, Narayan Rai JP. Induction of non protein thiols and phytohelatins by cadmium in Eichhornia crassipes. Int J Phytoremedition. 2019;21(8):790-98. https://doi.org/10.1080/15226514.2019.1566881

56. Ghori NH, Ghori T, Hayat MQ et al. Heavy metal stress and responses in plants. Int J Environ Sci Technol. 2019;16:1807-28. https://doi.org/10.1007/s13762-019-02215-8

57. Park HC, Hwang JE, Jiang Y, Kim YJ, Kim SH, Kim CY, Chuang WS. Functional characterization of two phytochelatin synthases in rice (Oryza sativa cv. Milyang 117) that respond to cadmium stress. Plant Biol. 2019;21(5):854-61. https://doi.org/10.1111/plb.12991

58. Zhang X, Rui H, Zhang F, Hu Z, Xia Y, Shen Z. Overexpression of a functional Vicia sativa PCS1 homolog increases cadmium tolerance and phytochelatin synthesis in Arabidopsis. Front Plant Sci. 2018;9:107. https://doi.org/10.3389/fpls.2018.00107

59. Shahid M, Pourrut B, Dumat C, Nadeem M, Aslam M, Pinelli E. Heavymetal-induced reactive oxygen species: phytotoxicity and physicochemical changes in plants. Reviews of Environmental Contamination and Toxicology. 2014;232:1-44. https://doi.org/10.1007/978-3-319-06746-9_1

60. Shimo $\mathrm{H}$, Ishimaru $\mathrm{Y}$, An $\mathrm{G}$, Yamakawa $\mathrm{T}$, Nakanishi $\mathrm{H}$, Nishizawa NK: Low cadmium (LCD), a novel gene related to cadmium tolerance and accumulation in rice. Journal of Experimental Botany. 2011;62(15):5727-34.10.1093/jxb/err300

61. Song J, Feng SJ, Chen J, Zhao WT, Yang ZM. A cadmium stressresponsive gene AtFC1 confers plant tolerance to cadmium $\begin{array}{llll}\text { toxicity. BMC } & \text { Plant } & \text { Biol. } & \end{array}$ https://doi.org/10.1186/s12870-017-1141-0

62. Lata S, Kaur HP, Mishra T. Cadmium bioremediation: a review. Int J Pharm Sci Res. 2019;10(9):4120-28. https://doi.org/10.13040/IJPSR.0975-8232.10(9).4120-28

63. Li Q, Wang G, Wang Y, Yang D, Guan C, Ji J. Foliar application of salicylic acid alleviate the cadmium toxicity by modulation the reactive oxygen species in potato. Ecotoxicol Environ Saf. 2019;172:317-25. https://doi.org/10.1016/j.ecoenv.2019.01.078

64. Tajti J, Nemeth E, Glatz G, Janda T, Pál M.Pattern of change in salicylic acid induced protein kinase (SIPK) gene expression and salicylic acid accumulation in wheat under cadmium exposure. Plant Biol. 2019;21(6):1176-80. https://doi.org/10.1111/plb.13032

65. Paul S, Dey S, Kundu R. Genomics and genetic engineering to develop metal/metalloid stress-tolerant rice. In rice research for quality improvement: Genomics and genetic engineering 2020:327-56. Springer, Singapore.

66. Kudo K, Kudo H., Kawai S. Cadmium uptake in barley affected by iron concentration of the medium: Role of phytosiderophores. Soil Science and Plant Nutrition. 2007;53(3):259-66. https://doi.org/10.1111/j.17470765.2007.00131.x

67. Curie C, Cassin G, Couch D, Divol F, Higuchi K, Le Jean M, Misson J, Schikora A, Czernic P, Mari S. Metal movement within the plant: contribution of nicotianamine and yellow stripe 1-like transporters. Ann Bot. 2009;103(1):1-11. https://doi.org/10.1093/aob/mcn207

68. Nakanishi H, Ogawa I, Ishimaru Y, Mori S, Nishizawa NK. Iron deficiency enhances cadmium uptake and translocation mediated by the $\mathrm{Fe}^{2+}$ transporters OsIRT1 and OsIRT2 in rice. Soil Sci Plant Nutr. 2006;52(4):464-69. https://doi.org/10.1111/j.1747-0765.2006.00055.x

69. Pedas P, Ytting CK, Fuglsang AT, Jahn TP, Schjoerring JK, Husted S. Manganese effi- ciency in barley: Identification and characterization of the metal ion transporter HvIRT1. Plant Physiol. https://doi.org/10.1104/pp.108.118851

70. BarberonM, Dubeaux G, Kolb C, Isono E, Zelazny E, Vert G. 2014. Polarization of IRON-REGULATED TRANSPORTER 1 (IRT1) to the plant-soil interface plays crucial role in meta homeostasis. Proc Natl Acad Sci. USA. 2014;111(22):8293-98. https://doi.org/10.1073/pnas.1402262111

71. Abedi T, Mojiri A. Cadmium Uptake by Wheat (Triticum aestivum L.): An Overview. Plants (Basel). 2020;14;9(4):500. https://doi.org/10.3390/plants9040500

72. Lin Y-F, Hassan Z, Talukdar S, Schat H, Aarts MGM. Expression of the ZNT1 zinc transporter from the metal hyper accumulator Noccaea caerulescens confers enhanced zinc and cadmium tolerance and accumulation to Arabidopsis thaliana.
PLOS
ONE.
2016:11:e0149750. https://doi.org/10.1371/journal.pone.0149750

73. Chen X, Ouyang Y, Fan Y, Qiu B, Zhang G, Zeng F. The pathway of transmembrane cadmium influx via calcium-permeable channels and its spatial characteristics along rice root. J Exp Bot. 2018;69(21):5279-91. https://doi.org/10.1093/jxb/ery293

74. Perriguey J, Sterckeman T, MorelJL. Effect of rhizosphere and plant-related factors on the cadmium uptake by maize (Zea mays L.). Environ Exp Bot. 2008;63(3):333-41. https://doi.org/10.1016/j.envexpbot.2007.12.014

75. Tang L, Mao B, Li Y, Lv Q, Zhang L, Chen C, He H, Wang W, Zeng X, Shao Y, PanY, Hu Y, Peng Y, Fu X, Li H, Xia S, Zhao B. Knockout of OsNramp5 using the CRISPR/Cas9 system produces low Cd-accumulating indica rice without compromising yield. Sci Rep. 2017;7(1):14438. https://doi.org/10.1038/s41598-017-14832-9

76. Sui F, Zhao D, Zhu H, Gong Y, Tang Z, Huang XY, Zhang G, Zhao FJ. Map-based cloning of a new total loss-of-function allele of OsHMA3 causes high cadmium accumulation in rice grain. J Exp Bot. 2019;70(10):2857-71. https://doi.org/10.1093/jxb/erz093

77. Thomine S, WangR, Ward JM, Crawford NM, Schroeder JI Cadmium and iron transport by members of a plant metal transporter family in Arabidopsis with homology to Nramp genes. Proc Natl Acad Sci. USA. 2000;97(9):4991-96. https://doi.org/10.1073/pnas.97.9.4991

78. Feng S, Tan J, Zhang Y, Liang S, Xiang S, Wang H, Chai T. Isolation and characterization of a novel cadmium-regulated Yellow Stripe-Like transporter (SnYSL3) in Solanum nigrum. Plant Cell Rep. 2017;36:281-96. https://doi.org/10.1007/s00299016-2079-7

79. Koike S, Inoue H, Mizuno D, Takahashi M, Nakanishi H, Mori S Nishizawa NK. OsYSL2 is a rice metal-nicotianamine transporter that is regulated by iron and expressed in the phloem. Plant J. 2004;39:415-24. https://doi.org/10.1111/j.1365313X.2004.02146.x

80. Migocka M, Papierniak A, Kosieradzka A, Posyniak E, Maciaszczyk-Dziubinska E, Biskup R, Garbiec A, Marchewka T. Cucumber metal tolerance protein CsMTP9 is a plasma membrane $\mathrm{H}^{+}$-coupled antiporter involved in the $\mathrm{Mn}^{2+}$ and $\mathrm{Cd}^{2+}$ efflux from root cells. Plant J. 2015;84:1045-58. https://doi.org/10.1111/tpj.13056

81. Kim DY, Bovet L, Maeshima M, Martinoia E, Lee Y. The ABC transporter AtPDR8 is a cadmium extrusion pump conferring 
heavy metal resistance. Plant J. 2007;50(2):207-18 https://doi.org/10.1111/j.1365-313X.2007.03044.x

82. Peng JS, Ding G, Meng S, Yi HY, Gong JM. Enhanced metal tolerance correlates with heterotypic variation in SpMTL, a metallothionein-like protein from the hyperaccumulator Sedum plumbizincicola. Plant Cell Environ. 2017;40(8):1368-78. https://doi.org/10.1111/pce.12929

83. Kuramata M, Masuya S, Takahashi Y, Kitagawa E, Inoue C, Ishikawa S, Youssefi S, Kusano T. Novel cysteine-rich peptides from Digitaria ciliaris and Oryza sativa enhance tolerance to cadmium by limiting its cellular accumulation. Plant Cell Physiol. https://doi.org/10.1111/pce.1292910.1093/pcp/pcn175

84. Luo JS, Huang J, Zeng DL, Peng JS, Zhang GB, MaHL, Guan Y, Yi HY, Fu YL, Han B, Lin HX, Qian Q, Gong JM. A defensin-like protein drives cadmium efflux and allocation in rice. Nat. Commun. 2018;9:645. https://doi.org/10.1038/s41467-018-030880

85. Liu H, Zhao H, Wu L, Liu A, Zhao FJ, Xu W. Heavy metal ATPase 3 (HMA3) confers cadmium hypertolerance on the cadmium/zinc hyperaccumulator Sedum plumbizincicola. New Phytol. 2017;215(2):687-98._https://doi.org/10.1111/nph.14622

86. Shao JF, Xia J, Yamaji N, Shen RF, MaJF. Effective reduction of cadmium accumulation in rice grain by expressing OsHMA3 under the control of the OsHMA2 promoter. J Exp Bot. 2018;69(10):2743-52. https://doi.org/10.1093/jxb/ery107

87. Zhang L, Wu J, Tang Z, Huang XY, Wang X, Salt DE, Zhao FJ. Variation in the BrHMA3 coding region controls natural variation in cadmium accumulation in Brassica rapa $\begin{array}{lllll}\text { vegetables. J } & \text { Exp } \quad \text { Bot. 2019;70(20):5865-78. }\end{array}$ https://doi.org/10.1093/jxb/erz310

88. Schneider T, Schellenberg M, Meyer S, Keller F, Gehrig P, Riedel K, Lee Y, Eberl L, Martinoia E. Quantitative detection of changes in the leaf-mesophyll tonoplast proteome in dependency of a cadmium exposure of barley (Hordeum vulgare L.) plants. Proteomics. 2009;9:266877.https://doi.org/10.1002/pmic.200800806

89. Pittman JK, Shigaki T, Marshall JL, Morris JL, Cheng NH, Hirschi KD. Functional and regulatory analysis of the Arabidopsis thaliana CAX2 cation transporter. Plant Mol Biol. 2004;56:959-71. https://doi.org/10.1007/s11103-004-6446-3

90. Korenkov V, Park S, Cheng NH, Sreevidya C, Lachmansingh J, Morris J, Hirschi K,Wagner GJ. Enhanced $\mathrm{Cd}^{2+}$-selective roottonoplast- transport in tobaccos expressing Arabidopsis cation exchangers. Planta. https://doi.org/10.1007/s00425-006-0352-7

91. Brunetti P, Zanella L, De PA, Di LD, Cecchetti V, Falasca G. Cadmium-inducible expression of the ABC-type transporter AtABCC3 increases phytochelatin-mediated cadmium tolerance in Arabidopsis. J Exp Bot. 2015;66(13):3815-29. https://doi.org/10.1093/jxb/erv185

92. Oomen RJFJ, Wu J, Lelièvre F, Blanchet $S$, Richaud P, BarbierBrygoo H, AartsMGM, Thomine S. Functional characterization of NRAMP3 and NRAMP4 from the metal hyperaccumulator Thlaspi caerulescens. New Phytol. 2008;181(3):637-50. https://doi.org/10.1111/j.1469-8137.2008.02694.x

93. Wong CKE, Cobbett CS. HMA P-type ATPases are the major mechanism for root-to-shoot Cd translocation in Arabidopsis thaliana. New Phytol. 2009;181(1):71-78. https://doi.org/10.1111/j.1469-8137.2008.02638.x

94. Craciun AR, Meyer CL, Chen J, Roosens N, Groodt RD, Hilson P, Verbruggen N. Variation in HMA4 gene copy number and expression among Noccaea caerulescens populations presenting different levels of $\mathrm{Cd}$ tolerance and accumulation. J Exp Bot. 2012;63(11):4179-89. https://doi.org/10.1093/jxb/ers104

95. Hanikenne M, Talke IN, Haydon MJ, LanzC, Nolte A, Motte P, Kroymann J, Weigel D, Krämer U. Evolution of metal hyperaccumulation required cis-regulatory changes and triplication of HMA4. Nature. 2008;453(7193):391-96. https://doi.org/10.1038/nature06877

96. Yuan L, Yang S, Liu B, Zhang M, Wu K. Molecular characterization of a rice metal tolerance protein, OsMTP1. Plant Cell Rep. 2012;31(1):67-79. https://doi.org/10.1007/s00299011-1140-9

97. Hao X, Zeng M, Wang J, Zeng Z, Dai J, Xie Z, Yang Y, Tian L, Chen L, Li D. A node-expressed transporter OsCCX2 is involved in grain cadmium accumulation of rice. Frontiers Plant Sci. 2018;9:476. https://doi.org/10.3389/fpls.2018.00476
98. Uraguchi S, Kamiya T, Clemens S, Fujiwara T. Characterization of OsLCT1, a cadmium transporter from indica rice (Oryza sativa). Physiol Plant. 2014;151(3):339-47. https://doi.org/10.1111/ppl.12189

99. Yamaji N, Ma JF. Node-controlled allocation of mineral elements in Poaceae. Curr Opin Plant Biol. 2017;39:18-24. https://doi.org/10.1016/j.pbi.2017.05.002

100. Subramaniam MN, Goh PS, Lau WJ, Ismail AF. The Role of nanomaterials in conventional and emerging technologies for heavy metal removal: A state-of-the-art review. Nanomaterials. 2019;9(4):625. https://doi.org/10.3390/nano9040625

101. Baskar V, Meeran S, Shabeer TK, Subramani A, Sruthi, Ali J. Historic review on modern herbal nanogel formulation and delivery methods. Int J Pharm Pharm Sci. 2018;10(10):1-10. https://doi.org/10.22159/ijpps.2018v10i10.23071

102. Huynh KH, Pham XH, Kim J, Lee SH, Chang R, Jun BH. Synthesis properties and biological applications of metallic alloy nanoparticles. Int J Mol Sci. 2020;21(14):5174. https://doi.org/10.3390/ijms21145174

103. Khan I, Saeed K, Khan I. Nanoparticles: Properties, applications and toxicities. Arabian Journal of Chemistry. 2019;12(7):908-31. https://doi.org/10.1016/j.arabjc.2017.05.011

104. Neamtu I, Rusu AG, Diaconu A, Nita LE, Chiriac AP. Basic concepts and recent advances in nanogels as carriers for medical applications. Drug Deliv. 2017;24(1):539-57. https://doi.org/10.1080/10717544.2016.1276232

105. Avellan A, Schwab F, Masion A, Chaurand P, Borschneck D, Vidal V, Rose J, Santaella C, Levard C. Nanoparticle uptake in plants: gold nanomaterial localized in roots of Arabidopsis thaliana by X-ray computed nanotomography and hyperspectral imaging. Environ Sci Technol. 2017;51(15):868291. https://doi.org/10.1021/acs.est.7b01133

106. Zou Y, Wang X, Khan A, Wang P, Liu Y, Alsaedi A, Hayat T, Wang X. Environmental remediation and application of nanoscale zero-valent iron and its composites for the removal of heavy metal ions: a review. Environ Sci Technol. 2016;50:7290-304. https://doi.org/10.1021/acs.est.6b01897

107. Sebastian A, Nangia A, Prasad MNV. Cadmium and sodium adsorption properties of magnetite nanoparticles synthesized from Hevea brasiliensis Muell. Arg. bark: Relevance in amelioration of metal stress in rice. J Hazard Mater. 2019;371, 261-72. https://doi.org/10.1016/j.hazmat.2019.03.021

108. Wang Y, Liu Y, Zhan W, Zheng K, Lian M, Zhang C, Ruan X, Li T Long-term stabilization of $\mathrm{Cd}$ in agricultural soil using mercapto-functionalized nano-silica (MPTS/nano-silica): A three-year field study. Ecotoxicol Environ Saf 2020;197:110600. https://doi.org/10.1016/j.ecoenv.2020.110600

109. Cui H, Shi Y, Zhou J, Chu H, Cang L, Zhou D. Effect of different grain sizes of hydroxyapatite on soil heavy metal bioavailability and microbial community composition. Agric Ecosyst Environ https://doi.org/10.1016/j.agee.2018.08.017

110. Guha T, Barman S, Mukherjee A, Kundu R. Nano-scale zero valent iron modulates $\mathrm{Fe} / \mathrm{Cd}$ transporters and immobilizes soil $\mathrm{Cd}$ for production of $\mathrm{Cd}$ free rice. Chemosphere. 2020;260:127533.

https://doi.org/10.1016/j.chemosphere.2020.127533

111. Ahmed T, Noman M, Manzoor N, Shahid M, Abdullah M, Ali L, Wang G, Li B. Nanoparticle based amelioration of drought stress and cadmium toxicity in rice via triggering the stress responsive genetic mechanisms and nutrient acquisition. Eco Environ Safe. https://doi.org/10.1016/j.ecoenv.2020.111829

112. Pulido-Reyes G, Rodea-Palomares I, Das S, Sakthivel TS, Leganes F, Rosal R, Seal S, Fernandez-Pin $\sim$ as F. Untangling the biological effects of cerium oxide nanoparticles: The Role of Surface Valence States. Sci Rep. 2015, 5, 15613.

113. Wu H, Tito N, Giraldo JP. Anionic Cerium Oxide Nanoparticles Protect Plant Photosynthesis from Abiotic Stress by Scavenging Reactive Oxygen Species. ACS Nano. 2017;11:11283-97. https://doi.org/10.1021acsnano.7b0523

114. Gohari G, Mohammadi A, Akbari Ali, Panahirad S, Dadpour MR, Fotopoulos V, Kimura S. Titanium dioxide nanoparticles promote growth and ameliorate salinity stress effects on essential oil profile and biochemical attributes of Dracocephalum moldavica. Scientific Reports. 2020;10:912. https://doi.org/10.1038/s41598-020-57794-1

115. Ogunkunle CO, Gambari H, Agbaje F, Okoro HK, Asogwa NT, Vishwakarma V, Fatoba PO. Effect of Low-Dose Nano Titanium 
Dioxide Intervention on $\mathrm{Cd}$ Uptake and Stress Enzymes Activity in Cd-Stressed Cowpea [Vigna unguiculata (L.) Walp] Plants. Bulletin of Environmental Contamination and Toxicology. 2020;104:619-26. https://doi.org/10.1007/s00128020-02824-x

116. JiY, Zhou Y, Ma C, Feng Y, Hao Y, Rui Y, Wu W, Gui X, Le VN, Han Y, Wang Y, Xing B, Liu L, Cao W. Jointed toxicity of TiO NPs and Cd to rice seedlings: NPs alleviated Cd toxicity and Cd promoted NPs uptake. Plant Physiol. Biochem. 2017;110:82-93. https://doi.org/10.1016/j.plaphy.2016.05.010

117. Lian J, Zhao L, Wu J, Xiong H, Bao Y, Zeb A, Tang J, Liu W. Foliar spray of $\mathrm{TiO}_{2}$ nanoparticles prevails over roo application in reducing $\mathrm{Cd}$ accumulation and mitigating $\mathrm{Cd}$ induced phytotoxicity in maize (Zea mays L.). Chemosphere. 2020:239:124794

https://doi.org/10.1016/j.chemosphere.2019.124794

118. Ahmad P, Allah EA, Hashem A, Sarwat M, Gucel S. Exogenous application of selenium mitigates cadmium toxicity in Brassica juncea (L.)(Czern.) by up-regulating anti-oxidative system and secondary metabolites. J. Plant Growth Regul. 2016;35:936-50. https://doi.org/10.3390/plants9070904

119. Khan MIR, Nazir F, Asgher M, Per TS, Khan NA. Selenium and sulfur influence ethylene formation and alleviate cadmiuminduced oxidative stress by improving proline and glutathione production in wheat. J Plant Physiol. 2015;173:9-18. https://doi.org/10.1016/j.jplph.2014.09.011

120. Ikram M, Javed B, Raja NI, Mashwani ZUR. Biomedica potential of plant based selenium nanoparticles: a comprehensive review on therapeutic and mechanistic aspects. Int J Nanomedicine. 2021;12(16):249-68. https://doi.org/10.2147/IJN.S295053

121. Olivera S, Chaitra K, Venkatesh K, Muralidhara HB, Inamuddin, Asiri A, Ahamed MI. Cerium oxide and composites for the removal of toxic metal ions. Environmental Chemistry Letters. 2018;16:1233-46. https://doi.org/10.1007/s10311-0180747-2

122. Cao Z, Stowers C, Rossi L, Zhang W, Lombardini L, Ma X Physiological effects of cerium oxide nanoparticles on the photosynthesis and water use efficiency of soybean (Glycine $\max$ (L.) Merr.). Environ Sci Nano. 2017;4:1086-94. https://doi.org/10.1039/C7EN00015D

123. Rossi L, Sharifan H, Zhang W, Schwab AP. Mutual effects and in planta accumulation of co-existing cerium oxide nanoparticles and cadmium in hydroponically grown soybean (Glycine max (L.) Merr.). Environmental Science Nanos. 2018;5:150-57. https://doi.org/10.1039/C7EN00931C

124. Wang Y, Wang L, MaC, Wang K, Hao Y, Chen Q, Mo Y, Rui Y. Effects of cerium oxide on rice seedlings as affected by coexposure of cadmium and salt. Environ Pollut. 2019;252:108796. https://doi.org/10.1016/j.envpol.2019.06.007

125. Rossi L, Weilan Z, Schwab AP, Xingmao Ma. Uptake accumulation and in planta distribution of coexisting cerium oxide nanoparticles and cadmium in Glycine $\max (\mathrm{L}$.$) Merr$ Environmental Science and Technology. 2017;51(21):12815-24. https://doi.org/10.1021/acs.est.7b03363

126. Wang S, Wang F, Gao S. Foliar application with nano-silicon alleviates Cd toxicity in rice seedlings. Environ Sci Pollut Res. 2015;22(4):2837-45. https://doi.org/10.1007/s11356-014-3525-0

127. Hussain B, Lin Q,Hamid Y,Sanaullah M, Di L, Hashmi MLUR, Khan MB, He Z, Yang X . Foliage application of selenium and silicon nanoparticles alleviates $\mathrm{Cd}$ and $\mathrm{Pb}$ toxicity in rice (Oryza sativa L.) Sci Total Environ. 2020;10:712:136497. https://doi.org/10.1016/j.scitotenv.2020.136497

128. Chen R, Zhang C, Zhao Y, Huang Y, Liu Z. Foliar application with nano-silicon reduced cadmium accumulation in grains by inhibiting cadmium translocation in rice plants. Environmental Science Pol Res. 2018;25(3):2361-68. https://doi.org/10.1007/s11356-017-0681-z

129. Ali S, Rizwan M, Hussain A, Rehman MZU, Ali B, Yousaf B, Wijaya L, Alyemeni MN, Ahmad P. Silicon nanoparticles enhanced the growth and reduced the cadmium accumulation in grains of wheat (Triticum aestivum L.) Plant Physiol Biochem.

https://doi.org/10.1016/j.plaphy.2019.04.041

2019;140:1-8.

130. Li Z and Huang J. Effects of nanoparticle hydroxyapatite on growth and antioxidant system in Pakchoi (Brassica chinensis L.) from cadmium contaminated soil. Journal of Nanomaterials. 2014. http://dx.doi.org/10.1155/2014/470962
131. He M, Shi H, Zhao X, Yu Y, Qu B. Immobilization of $\mathrm{Pb}$ and $\mathrm{Cd}$ in contaminated soil using nano-crystallite hydroxyapatite. Procedia Environ Sci. 2013;18:657-65. https://doi.org/10.1016/j.proenv.2013.04.090

132. QingqingZ, Shuokang W, Chenchen Z, Qing W, Ying Z, Lin N, Shu Xuan L, Wei L. Adsorption and Desorption of Cd on nHAP and Remediation test on Cd Contaminated Soil Environ Eng. 2017;35:179-84.

133. Dey S, Kundu R, Gopal G, Mukherjee A, Nag A, Paul S. Enhancement of nitrogen assimilation and photosynthetic efficiency by novel iron pulsing technique in Oryza sativa I. var. pankaj. Plant Physiol Biochem. 2019;144:207-21. https://doi.org/10.1016/j.plaphy.2019.09.037

134. Dey S, Paul S, Nag A, Banerjee R, Gopal G, Mukherjee A, Kundu R. Iron-pulsing, a novel seed invigoration technique to enhance crop yield in rice: A journey from lab to field aiming towards sustainable agriculture. Sci Tot Environ. 2021;769:144671.

https://doi.org/10.1016/j/scitotenv.2020.144671

135. Konate A, He X, Zhang Z, Ma Y, Zhang P, Alugongo GM, Rui Y. Magnetic $\left(\mathrm{Fe}_{3} \mathrm{O}_{4}\right)$ nanoparticles reduce heavy metals uptake and mitigate their toxicity in wheat seedling. Sustainability. 2017;9(5):790. https://doi.org/10.3390/su9050790

136. Wan Z, Cho DW, Tsang DCW, Li M, Sun T, Verpoort F. Concurrent adsorption and micro-electrolysis of $\mathrm{Cr}(\mathrm{VI})$ by nanoscale zerovalent iron/biochar/Ca-alginate composite. Environ Pollut. 2019;247:410-20. https://doi.org/10.1016/j.envpol.2019.01.047

137. López-Luna L, Silva-Silva MJ, Martinez-Vargas S, MijangosRicardez OF, González-Chávez MC, Solís-Domínguez FA Cuevas-Díaz MC. Magnetite nanoparticle (NP) uptake by wheat plants and its effect on cadmium and chromium toxicological behavior. Sci Total Environ. 2016;565:941-50. https://doi.org/10.1016/j.scitotenv.2016.01.029

138. Li M, Zhang P, Adeel M, Guo Z, Chetwynd AJ, Ma C, Bai T, Hao $\mathrm{Y}$, Rui Y . Physiological impacts of zero valent iron, $\mathrm{Fe}_{3} \mathrm{O}_{4}$ and $\mathrm{Fe}_{2} \mathrm{O}_{3}$ nanoparticles in rice plants and their potential as $\mathrm{Fe}$ fertilizers. Environ Pollut 2020;269:116134. https://doi.org/10.1016/j.envpol.2020.116134

139. Yoon H, Kang YG, Chang YS. Effects of zerovalent iron nanoparticles on photosynthesis and biochemical adaptation of soil grown Arabidopsis thaliana. Nanomaterials. 2019;9(11):1543. https://doi.org/10.3390/nano9111543

140. Guha T, Gopal G, Chatterjee R, Mukherjee A, Kundu R. Differential growth and metabolic responses induced by nano scale zero valent iron in germinating seeds and seedlings of Oryza sativa L. cv. Swarna. Ecotoxicol Environ Saf. 2020;204:111104. https://doi.org/10.1016/j.ecoenv.2020.111104

141. Hussain A, Ali S, Rizwan M, Rehman MZU, Qayyum MF, Wang $\mathrm{H}$, Rinklebe J. Responses of wheat (Triticum aestivum) plants grown in a $\mathrm{Cd}$ contaminated soil to the application of iron oxide nanoparticles. Ecotoxicology and Environmental Safety. 2019;173:156-64. https://doi.org/10.1016/j.ecoenv.2019.01.118

142. Gong X, Huang D, Liu Y and Zeng G. Stabilized nanoscale zerovalent iron mediated cadmium accumulation and oxidative damage of Boehmeria nivea (L.) Gaudich cultivated in cadmium contaminated sediments. Environ Sci Technol. 2017;51, 19:11308-16. https://doi.org/10.1021/acs.est.7b03164

143. Li J, Hu J, Ma C, Wang Y, Wu C, Huang J, Xing B. Uptake, translocation and physiological effects of magnetic iron oxide $\left(\gamma-\mathrm{Fe}_{2} \mathrm{O}_{3}\right)$ nanoparticles in corn (Zea mays L.). Chemosphere. 2016;159:326-34. https://doi.org/10.1016/j.chemosphere.2016.05.083

144. Rizwan M, Ali S, Ali B, Adrees M, Arshad M, Hussain A, Rehman MZU, Waris AA. Zinc and iron oxide nanoparticles improved the plant growth and reduced the oxidative stress and cadmium concentration in wheat. Chemosphere. 2019;214:269-77. https://doi.org/10.1016/j.chemosphere.2018.09.120

145. Guha T, Ravikumar KV, Mukherjee A, Kundu R. Nanopriming with zero valent iron (nZVI) enhances germination and growth in aromatic rice cultivar (Oryza sativa cv. Gobindobhog L.) Plant Physiol Biochem. 2018;127:403-13. https://doi.org/10.1016/j.plaphy.2018.04.014

146. Guha T, Mukherjee, Kundu R. Nano scale zero valent iron (nZVI) priming enhances yield, alters mineral distribution and grain nutrient content of Oryza sativa L. cv. Gobindobhog: A field study. J Plant Growth Regul. 2021;https://doi.org/10.1007/s00344-021-10335-0 
147. Yang J, Hou B, Wang J, Tian B, Bi J, Wang N, Li X, Huang X. Nanomaterials for the removal of heavy metals from wastewater. Nanomaterials. 2019;9(3):424 https://doi.org/10.3390/nano9030424

148. Mustapha S, Ndamitso MM., Abdulkareem AS, Tijani JO, Shuaib DT, Ajala AO, Mohammed AK. Application of $\mathrm{TiO}_{2}$ and $\mathrm{ZnO}$ nanoparticles immobilized on clay in wastewater treatment: a $\begin{array}{llll}\text { review. Appl Water } & \text { Sci. } & \text { 2020;10:49 }\end{array}$ https://doi.org/10.1007/s13201-019-1138-y

149. Zhang W, Long J, Li J, Zhang M, Xiao G, Ye X, Chang W, Zeng H Impact of ZnO nanoparticles on Cd toxicity and bioaccumulation in rice (Oryza sativa L.). Environmental Science and Pollution Research. 2019;26(22):23119-28 https://doi.org/10.1007/s11356-019-05551-X

150. Faizan M, Faraz A, Mir AR, Hayat S. Role of zinc oxide nanoparticles in countering negative effects generated by cadmium in Lycopersicon esculentum. J Plant Growth Regul. 2021;40:101-15._https://doi.org/10.1007/s00344-019-10059-2

151. Venkatachalam P, Jayaraj M, Manikandan R, Geetha N, Rene ER, Sharma NC, Sahi SV. Zinc oxide nanoparticles (ZnONPs) alleviate heavy metal-induced toxicity in Leucaena leucocephala seedlings: A physiochemical analysis. Plant Physiol Biochem. 2017;110:59-69. https://doi.org/10.1016/j.plaphy.2016.08.022

152. Bashir A, Rizwan M, Ali S, Adrees M, Rehman MZU, Qayyum MF. Effect of composted organic amendments and zinc oxide nanoparticles on growth and cadmium accumulation by wheat; a life cycle study. Environ Sci Pollut Res. 2020;27(19):23926-36. https://doi.org/10.1007/s11356-02008739-8

153. Ali S, Rizwan M, Noureen S, Anwar S, Ali B, Naveed M, Abd Allah, EF, Alqarawi AA, Ahmad P. Combined use of biochar and zinc oxide nanoparticle foliar spray improved the plant growth and decreased the cadmium accumulation in rice (Oryza sativa L.) plant. Environ Sci Pollut Res. 2019;26(11):11288-99. https://doi.org/10.1007/s11356-019-04554$\mathrm{y}$

154. Chai M, Shi F, Li R, Liu L, Liu Y, Liu F. Interactive effects of cadmium and carbon nanotubes on the growth and metal accumulation in a halophyte Spartina alterniflora (Poaceae). Plant Growth Regulation. 2013;71(2). https://doi.org/10.1007/s10725-013-9817-4

155. Gong X, Huang D, Liu Y, Zeng G, Wang R, Xu P, Zhang C, Cheng $M$, Xue W, Chen S. Role of multiwall carbon nanotubes in phytoremediation: cadmium uptake and oxidative burst in Boehmeria nivea (L.) Gaudich. Environmental Science: Nano. 2019;6:851-62. https://doi.org/10.1039/C8EN00723C

156. Norizan MN, Moklis MH, Demon SZN, Norhana AH, Samsuri A Mohamad IS, Knight VF, Abdullah N. Carbon nanotubes: funtionalisation and their application in chemical sensors. Royal Society of Chemistry (RSC)Adv. 2020;12(9):43704-732. https://doi.org/10.1039/d0ra09438b

157. Cheng J, Sun Z, Li X, Yu Y. Effects of modified nanoscale carbon black on plant growth, root cellular morphogenesis and microbial community in cadmium-contaminated soil. Environ Sci Pollut Res. 2020;27:18423-33. https://doi.org/10.1007/s11356-020-08081-z

\section{Additional information}

Peer review information: Plant Science Today thanks Sectional Editor and the other anonymous reviewers for their contribution to the peer review of this work.

Reprints and permissions information is available at
https://horizonepublishing.com/journals/index.php/PST/open_access_policy

Publisher's Note: Horizon e-Publishing Group remains neutral with regard to jurisdictional claims in published maps and institutional affiliations.

To cite this article: Chakraborty S, Pal S, Paul S. Nanoparticles mediated cadmium toxicity amelioration in plants. Plant Science Today. 2021;8(4):897911. https://doi.org/10.14719/pst.2021.8.4.1254

Plant Science Today, published by Horizon e-Publishing Group, is covered by Scopus, Web of Science, BIOSIS Previews, Clarivate Analytics, etc. See https://horizonepublishing.com/journals/index.php/PST/indexing_abstracting 